\title{
Rules of the Game: Effects of a Game-based Metaphor on Instructional Activity Design and the Use of Student Mentors on Learning Outcomes in a Middle School General Science Class
}

Angie Dowling

West Virginia University

Follow this and additional works at: https://researchrepository.wvu.edu/etd

\section{Recommended Citation}

Dowling, Angie, "Rules of the Game: Effects of a Game-based Metaphor on Instructional Activity Design and the Use of Student Mentors on Learning Outcomes in a Middle School General Science Class" (2012). Graduate Theses, Dissertations, and Problem Reports. 194.

https://researchrepository.wvu.edu/etd/194

This Dissertation is protected by copyright and/or related rights. It has been brought to you by the The Research Repository @ WVU with permission from the rights-holder(s). You are free to use this Dissertation in any way that is permitted by the copyright and related rights legislation that applies to your use. For other uses you must obtain permission from the rights-holder(s) directly, unless additional rights are indicated by a Creative Commons license in the record and/ or on the work itself. This Dissertation has been accepted for inclusion in WVU Graduate Theses, Dissertations, and Problem Reports collection by an authorized administrator of The Research Repository @ WVU.

For more information, please contact researchrepository@mail.wvu.edu. 
Rules of the Game: Effects of a Game-based Metaphor on Instructional Activity Design and the Use of Student Mentors on Learning Outcomes in a Middle School General Science Class

\author{
Angie Dowling
}

\begin{abstract}
Dissertation submitted to the College of Human Resources and Education at West Virginia University in partial fulfillment of the requirementsfor the degree of

Doctor of Education

In

Instructional Design and Technology
\end{abstract}

\author{
Terence C. Ahern, Ph.D., Chair \\ Neal Shambaugh, Ph.D. \\ Marjorie Darrah, Ph.D. \\ Ugur Kale, Ph.D. \\ D.J. Hendricks, Ed.D. \\ Department of Technology, Learning \& Culture \\ Morgantown, West Virginia \\ 2012
}

Keywords: Trivial games, Serious Games, Epistemic Games, Student Mentors, StarLogo, Elaboration Theory (C) Angie Dowling, 2012 


\begin{abstract}
Rules of the Game: Effects of a Game-based Metaphor on Instructional Activity Design and the Use of Student Mentors on Learning Outcomes in a Middle School General Science Class

Angie Dowling

This study investigated the effects of a game-like environment on instructional activity design and the use of student mentors on learning outcomes in a middle school general science class. The participants for this study were 165 students, ages $13-14$ years old, who were enrolled in $8^{\text {th }}$ grade at a mid-Atlantic middle school. Two research questions were used to conduct the research:
\end{abstract}

1. Can science content be designed and successfully delivered instructionally using a gamelike learning environment?

2. Does the use of student mentors/assistants help direct and maintain the flow of the class away from the technological issues toward the necessary learning outcomes while also increasing the science content understanding acquired by the mentors while also increasing class and student engagement?

For this study an introductory biology unit was designed using a game-like curricular structure. Student mentors were utilized in order to aid focus on the content and not the technology. The results indicated that the instructional design of the unit using a game-like environment was successful and students exhibited learning. The mentor students were instrumental in steering their fellow students away from the "Siren's Call" of the instrument (in this case StarLogo) and enabled increased focus on the content.

Keywords: Trivial games, Serious Games, Epistemic Games, Student Mentors, StarLogo, Elaboration Theory 


\section{Biographical Sketch}

Angie Dowling was born on April 27, 1962 in Findlay, Ohio. She lived in Ohio until she was 15 years old at which time she moved to Wisconsin with her family. Angie always had the goal of being the first on both her paternal and maternal sides to attend and graduate college with a degree. Angie attended and graduated from the University of Wisconsin in 1985 with a Bachelor of Science degree in the Life Sciences. After graduation Angie worked as a research assistant in a medical school until she married in 1987 and moved to Jacksonville, Florida. In 1989 Angie moved to Morgantown, West Virginia and after her first child was born she decided to attain a master's degree in secondary education towards certification to teach. In 1995, Angie graduated from West Virginia University with a Master's degree in Secondary Education with a certification to teach General Science, Grades 5-12 and Biology, Grades 9-12. Angie currently is teaching $8^{\text {th }}$ grade General Science at Suncrest Middle School in Morgantown, WV. She has taught for 18 years, 17 of which have been spent at Suncrest. Angie currently resides in Grafton, West Virginia and can be reached at adowling@access.k12.wv.us or adowlingsms@gmail.com. 


\section{Dedication}

I would like to dedicate this dissertation to my students from the past three years, especially from the 2011-2012 school year. My students were with me all of the way through the doctoral process over the past three years, and many of them were instrumental in the process by participating as my mentor students and putting in the extra time to be trained in the use of StarLogo and become my "experts." I would like to thank my fellow teachers on my team at school for putting up with my dedication of time into my dissertation. I would like to thank my advisor, Dr. Terence Ahern for his support and guidance throughout the process and for introducing me to using games in education. My many thanks to Dr. Neal Shambaugh for unknowingly inspiring me to seek a future working more closely with pre-service teachers and to become an advocate for them. A special thank you to Dr. Marjorie Darrah for being a tremendous help to me while I worked on the statistics for this dissertation and being a wonderful friend through this process and supporting me. I specifically would like to thank Elaine Hatcher who has worked with me throughout this process. She has been with me since her tutor year with the Benedum Teacher Education Program at West Virginia University and as an intern has been an invaluable resource and help to me. Lastly I want to thank my family for their endless support in this process. Without their support this dissertation could never have happened. 


\section{Acknowledgements}

The task of writing this dissertation was not an individual enterprise; it would not have been accomplished without the guidance and support of many very important people. I express my deepest and heartfelt thank you to all of you. In particular I would like to express my deepest gratitude to the members of my doctoral committee. I would like to thank my dissertation chair and advisor, Dr. Terence C. Ahern for his advice, support, valuable feedback and guidance throughout this process. I very much look forward to working with him on many future projects. I would also like to thank Dr. Ahern for all of the Saturdays over the past 2 years that he has come to my school to work with my mentor students on StarLogo programming. He has always shown great patience with them (as well as myself) concerning the intricacies of the programming. I would also like to thank Dr. Ugur Kale for his feedback during the candidacy process; it was invaluable. Equally I would like to thank Dr. D.J. Hendricks for her thoughtful guidance regarding possible statistical methods to be considered for my research. A special thanks to Dr. Neal Shambaugh whose Instructional Design course taught me how to look at different parts of a paper individually before combining them into a whole. And finally, an equally special thank you to Dr. Marjorie Darrah for her valuable help with considering my statistical methods in the latter phase of my data analysis.

I would also like to thank Ann Crabtree of the Department of Technology, Learning and Culture at WVU. She has always been very patient and understanding of any questions that I have and has helped me understand this process a great deal. Her efficiency, friendliness, and professionalism are very much appreciated.

Many thanks go to my $8^{\text {th }}$ grade students who took part in this study. They were with me throughout the process and I sincerely hope they learned something valuable from this process as 
well. I would also like to thank my mentor students from my pilot study during 2010-2011 who came back to help train my mentor students this year. They came to school on Saturday mornings for no other reason than to help me with my project and I will always be thankful to them for their time. I would also like to thank my colleagues who have supported and encouraged me on numerous occasions throughout this process. I would specifically like to thank Monica McCartney and Traci DeWall for their help and encouragement, along with a kind ear whenever I needed to talk about my instructional design and writing process. I would like to extend a very special thank you to my intern from the West Virginia University Benedum Teacher Education Program, Elaine Hatcher. She has been with me for three years in my classroom and has co-taught with me from the very beginning. Her help during the data collection and writing process has been invaluable. I sincerely hope she has learned as much from me as I have from her during this experience.

I am deeply indebted to the members of my family. My husband, daughter, and son have been extremely understanding of the time and energy that I have invested in this process. A special thank you to my mother. She has always encouraged me to succeed form a very young age, and I owe my determination and stubbornness in wanting to achieve my success to her. 


\section{TABLE OF CONTENTS}

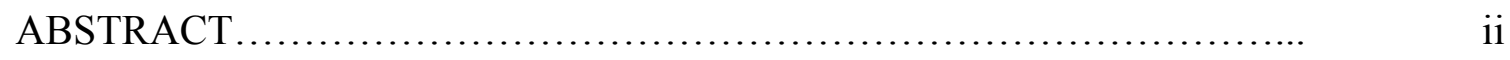

BIOGRAPHICAL SKETCH......................................

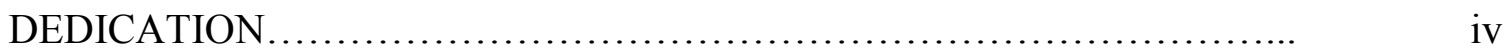

ACKNOWLEGEMENTS......................................... $\quad \mathrm{v}$

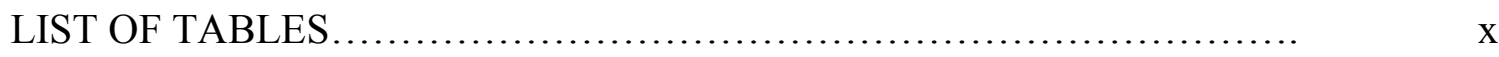

LIST OF FIGURES............................................ $\quad$ xi

\section{CHAPTER}

Background

Need for the Study and Rationale

Significance

Intervention

Research Questions

Definition of Terminology

Summary of the Introduction

II LITERATURE REVIEW

Introduction

Student Mentoring/Tutoring

Tell and Practice and the Alternatives 
Dynamic Systems and Agent-Based Modeling

Games, Motivation and the Magic Circle

Achievement and Motivation

Game-like Learning Environments

Summary of Literature Review

III

METHODOLOGY

Overview

Research Hypothesis

Methodology

Participants

Research Design

Data Sources

Procedure

Limitations

Summary of the Methodology

IV

FINDINGS ............................................

Overview

Modes of Data Analysis

Demographic Data

Major Findings

Research Question One

Research Question Two

V

DISCUSSION..........................................

Overview

Significance of the Study 
Limitations

Implications

Recommendations for Further Research

Summary

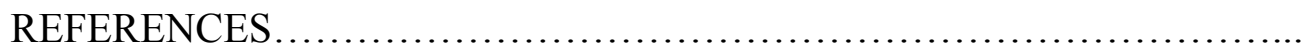

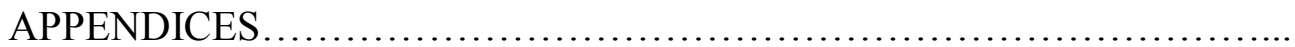

Appendix A: West Virginia Content Standards and Objectives for Eighth Grade Science

Appendix B: Rules of the Game

Appendix C: Game Level Descriptions

Appendix D: Blooms Digital Taxonomy

Appendix E: Level 1 Exit Ticket

Appendix F: Level 2 Exit Ticket

Appendix G: Level 3 Presentation Rubric

Appendix H: Pre-Test

Appendix I: Post-test

Appendix J: Student Engagement Checklist

Appendix K: Class Engagement Checklist

Appendix L: Data Sources 


\section{LIST OF TABLES}

Table 1 Pre-Test vs. Post-Test Scores Paired-Samples T-test for All Learners

Table 2 Overall Class Engagement Checklist.............................

Table 3 Overall Student Engagement Checklist...........................

Table 4 Student-Student Interactions vs. Student-Teacher Interactions.........

Table 5 Mentor Students Pre-Test vs. Post-test Scores.......................

Table 6 Pre-test vs. Post-Test Scores Paired-Samples T-test for Mentor

Learners............................................................. 


\section{LIST OF FIGURES}

Figure 1 StarLogo puzzle pieces for use in programing (Ahern, 2008).........

Figure 2 Pre-test vs. Post-test results for Period $2 \ldots \ldots \ldots \ldots \ldots \ldots \ldots \ldots \ldots \ldots \ldots \ldots$

Figure 3 Pre-test vs. Post-test results for Period $3 \ldots \ldots \ldots \ldots \ldots \ldots \ldots \ldots \ldots \ldots \ldots$

Figure 4 Pre-test vs. Post-test results for Period $4 \ldots \ldots \ldots \ldots \ldots \ldots \ldots \ldots \ldots \ldots$

Figure 5 Pre-test vs. Post-test results for Period $5 \ldots \ldots \ldots \ldots \ldots \ldots \ldots \ldots \ldots \ldots \ldots \ldots$

Figure 6 Pre-test vs. Post-test results for Period $6 \ldots \ldots \ldots \ldots \ldots \ldots \ldots \ldots \ldots \ldots \ldots$

Figure 7 Pre-test vs. Post-test results for Period $8 \ldots \ldots \ldots \ldots \ldots \ldots \ldots \ldots \ldots \ldots$

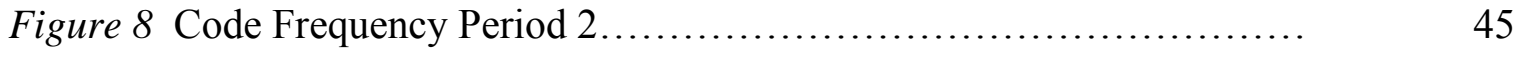

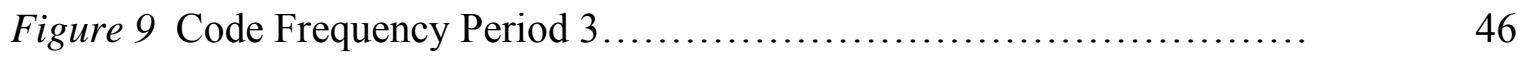

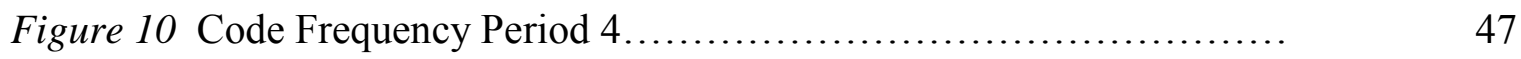

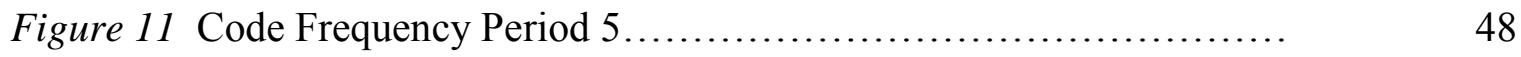

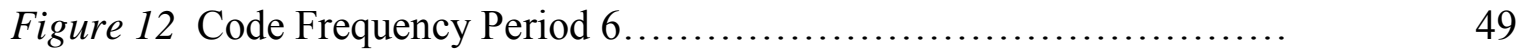

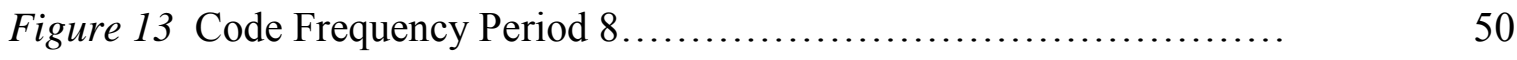

Figure 14 Mentors Pre-test vs. Post-test Score Distribution................. 52 
Rules of the Game: Effects of a Game-based Metaphor on Instructional Activity Design and the Use of Student Mentors on Learning Outcomes in a Middle School General Science Class

\section{Chapter I - Introduction}

\section{Background}

Scientific knowledge is a crucial skill for the 21 st Century. Consider that a hundred years ago, swamps were drained because they were perceived as a health threat. Now, because of our better scientific understanding, swamps are protected because they form an essential part of an ecosystem. Science gives us the tools to understand the world around us. However, our high school graduates are at risk. This trend is all the more troubling because the modern world demands a minimum of science literacy of all its citizens. The Nation's Report Card (NAEP, 2009) documents this decline in science knowledge among our nation's high school graduates. According to the National Assessment of Educational Progress, the nation's 12th graders are performing significantly lower than what 12th graders were doing only a decade earlier in 1996. Improving our children's awareness of scientific knowledge is difficult (Heibert \&Stigler, 2004). To improve our students' thinking about science is to change the way they learn about science. One way to achieve this paradigm shift is to engage today's learners with games, models and simulations.

Besides the fact that playing games are fun, games teach higher order thinking skills such as strategic thinking, interpretative analysis, problem solving, plan formulation and execution, and adaptation to rapid change (Klopfer, Osterweil \& Salen, 2009). According to Menn (1993), students remember about $10 \%$ of what they read, $20 \%$ of what they hear, and $30 \%$ of what they see. However, if they watch someone model something while explaining it, then their recall jumps to $50 \%$ and almost $90 \%$ if they are able to engage in the job themselves, even if it is only a simulation. 
Bateson (1972) states that game-based learning research has indicated that indicated that most gaming studies focus on learning conceptually - such as general reasoning, creativity, system understanding and decision making, These concepts do not demand any special knowledge of a particular content area. With many digital, computer-based games learning is not situated inside gameplay but outside of it. With these types of games, learners tend to be less engaged and persistent, especially when time passes and the games' sound effects and graphics become familiar. This pattern can cause the game to lose its ability to grab the learner's attention (Ke, 2008). Because of this many educational gaming researchers recommend that learning occur by stealth. With stealth learning, the learning outcome is engaging when it becomes concealed within the game and the learner is not conscious of it (Gee, 2003; Prensky, 2001). Game-like learning environments are of importance because game-based learning can be a hybrid, systematic process. Games are framed within the players' real-life physical surroundings and the players' interactions with these surroundings. The dynamics of peer interaction, the active guidance of a facilitator (or instructor), and the arrangement of the physical classroom environment will influence game-based learning outcomes (Ke, 2008). Kaptelin and Cole (2002) state that if learning outcomes are to be achieved through educational games it depends on the context of the instructional activities. Research into game-like learning environments should focus on not only how these games can be designed for learning purpose, but also how these same games can be aligned with sound instructional practices and design. Game-like learning environments coupled with interactive simulations have the ability to increase motivation while also increasing learning outcomes (Prensky, 2002). This is beneficial for today's educators since engaged and motivated learners tend to have increased learning outcomes (Vogel, Vogel, Cannon-Bowers, Bowers, Muse \& Wright, 2006). 
Although the use of games and simulations in the classroom can contribute to learning, there are barriers to adoption and implementation which originate from different sectors of society including industry, academia, the market, schools, and even the kids, themselves (Klopfer, et al., 2009). In order to overcome these barriers, effective learning outcomes in conjunction with appropriate instructional strategies and designs for the integration of games in the classroom must be demonstrated.

However, there are no magical formulas for a good educational game. One key is in how to frame the problem. In order to successfully implement games (or game-like activities) and simulations in the classroom, teachers need to find the fun in the learning. Teachers need to infuse the classroom with those game elements that make the game fun - goals, rewards, and competition. These game elements create intrinsic meaning. In this way, teachers can fully integrate the content and learning while also making the process fun. Students would want to simply "play the game" because of the overall experience. Educators need to devise a way to focus the students such that the learning experience is enhanced by the "fun" (Baker, 2008) of playing. One way of accomplishing this is to design the activities within a game-like learning environment where content can be covered from basic to most complex in an engaging way (elaboration theory of design).

\section{Need for the Study and Rationale}

The West Virginia Content Standards and Objectives for eighth grade dictate that students must master ecology content concerning food webs during the school year. Students tend to become bored with this content since it is a review for them. For some educators, this content tends to be covered at the beginning of the school year since it is a way to ease the students into the dynamics of the classroom. In order to relieve this boredom for the students, it 
is possible that a more exciting way of focusing their attention on the content would be to allow them to manipulate and interact with a basic model of an ecosystem.

A basic model of a forest ecosystem was constructed using the StarLogo software (Ahern, 2008; Massachusetts Institute of Technology, 2008). StarLogo is an example of a software program using dynamic systems and agent-based modeling. During whole class instruction the students examined a simplified computer model of a forest ecosystem; it was noticed that the students were often more focused on the software than the science literacy skills needed to examine the workings of the ecosystem. The students seemed to become lured away from the actual content by the "Siren's Call" much like Odysseus in his voyage home.

When using sophisticated data modeling software such as StarLogo, it is often difficult for students and teachers alike to ignore the "siren call of the instrument." There is a tendency to shift their focus to the tool instead of on the learning outcomes, which in this case are the science literacy skills. The difficulty, on the one hand, is to maintain lesson focus while on the other dealing with the inherent difficulties this type of software poses for instruction. There had to be a way to balance these competing needs.

One way to accomplish this balance would be to train student-to-student mentors who would have enough prior knowledge of the software in order for them to be able to deal with the inevitable problems that crop up during whole classroom instruction thereby freeing the teacher to concentrate on the science and the model. The mentors would intervene with specific students who were having software issues and thereby help the entire class stay focused on the intended learning outcome. These student mentors would help steer the class past the "siren call of the instrument." 


\section{Significance}

Today's students live in a culture dominated by activity and multi-tasking. Instructional activities should be adapted in such a way that the students can maintain focus and still remain actively engaged in order to acquire the requisite skill and knowledge. Games provide just such an environment. Game play increases concentration and interest while increasing the motivation to risk. The "player" evaluates game play and makes interpretations of their play of the "game." Based upon that evaluation, they are able to expand their ability. The key is to encourage students to engage with the content in the classroom as if it were a game. When key elements of game design are incorporated into instructional design of curriculum, engaging instructional activities can result. In effect, the students become part of the magic circle where they enter into the "game" (instructional activity) by "playing" with the knowledge and skill. By designing instruction and educational activities using a game-like environment the depth of knowledge can be increased.

\section{Intervention}

The dissertation study examines the delivery of science content using a game-design metaphor that uses student mentors in the classroom. Games can be examined on a continuum from trivial to epistemic games. Trivial games are essentially self-contained and do not extend into the real world. Checkers would be an example of a trivial game. In contrast, epistemic games can have a real purpose; players can learn purposeful skills and knowledge without consequence. For example, an airline pilot can learn a new technique without the inherent danger in flying a real plane. Serious games on the other hand are between trivial and epistemic games. The players do not overtly learn anything truly transferable but there are echoes of importance. 
For example, Mortimer: Adventures of an Eco-detective is basically a game where frogs can talk but it has real world connections by dealing with river pollution (echo of importance).

This study focuses on the use of serious games and simulations in the classroom using a game-like learning environment. Games are rule-based and each level of science content can be considered a "level" of the game with certain rules that must be followed in order to advance to the next level of the content. Student mentors could help maintain classroom focus as well as helping every student could become a "teacher."

Science content is recursive as well as iterative. Prior knowledge of the content is reviewed and used to internalize more advanced content. In this way, one can advance through the content from basic to more advanced material. Just as in a game, prior experience informs current play throughout the levels of the game. By using a game-like learning environment for delivery of the science content, a recursive environment was created in which students applied what they had learned over time. The content that was studied for this study was based on the $8^{\text {th }}$ grade science content for biology (Appendix A), from the more basic content on cells, on to systems and culminating in the study of how an epidemic functions. Since learning in a gamelike environment can increase the possibility of students becoming engaged and motivated and therefore also increase learning outcomes, the unit was embedded within this type of environment and incorporated the use of mentors while programming an epidemic using StarLogo.

\section{Research Questions}

RQ1: Can science content be designed and successfully delivered instructionally using a game-like learning environment? 
RQ2 - Will the use of student mentors/assistants help direct and maintain the flow of the class away from the technological issues toward the necessary learning outcomes while also increasing the science content understanding acquired by the mentors themselves while also increasing class and student engagement?

\section{Definition of Terminology}

Elaboration Theory: a process for designing instruction that is used quite often by inservice K12 teachers for designing instruction. In Elaboration Theory content is delivered from the simplest concepts to the most complex (Wilson \& Cole, 1992).

Epistemic Games: Games that are meant not only for learning but also for solving problems in real world situations. Playing epistemic games go beyond simple learning and approach development of the skills learned so that they can be put to use in real life.

Flow Theory: Csikszentmihalyi (1990) defines flow theory as a method for understanding and implementing motivation. Flow theory requires a perfect balance between challenge and frustration. The end goal becomes so clear that any hindrances disappear. The learner becomes completely involved in an activity by being provided with a challenge, setting goals, having structured control and being provided with clear feedback.

Magic Circle: Huizinga (1955) states that the Magic Circle is an imaginary aspect of a game in which a player can risk, explore and think without consequence. Any time spent in the Magic Circle is time spent away from everyday life and the surroundings.

Serious Games: Game-based materials used for learning and educational purposes.

StarLogo: Modeling and simulation software created by Massachusetts Institute of Technology (2010). Programming is accomplished by using a drag and drop puzzle piece format 
(Ahern, 2008). Models can be programmed and altered within the StarLogo software and various outcomes can be observed.

\section{Summary of the Introduction}

The rationale for this chapter was to present background information regarding the dissertation and to briefly describe the research problem. This chapter covers the rationale for the chapter, and additionally discusses the need for the study and the problem statement. It begins by discussing the importance of developing $21^{\text {st }}$ century skills and how the concept of utilizing game-like learning environments in the classroom can be instrumental in developing those skills. Since there are barriers to the implementation of different types of games in the classroom from various viewpoints it is important for research to demonstrate how the use of various games in the classroom can improve learning outcomes. This chapter also discusses how the mechanics of game design and learning to "play" the game can interfere with the learning outcomes by taking the focus of both the teacher and learners away from the content and directing it towards game mechanics (the "Siren Call" of the instrument). The chapter also introduces the research questions. The following chapter presents a detailed discussion of the literature review that will be used for this study. This chapter will also include a discussion of student mentoring/tutoring, dynamic systems and agent-based modeling, design of instruction and games, motivation and the concept of the Magic Circle in game design. 


\section{Chapter II - Literature Review}

\section{Introduction}

This chapter presents a detailed literature review regarding the use of student mentors, dynamic systems and agent-based modeling, games, motivation and the magic circle in the classroom and how all of these are related to design of instruction. Because all of these areas are integrated in their importance to the dissertation study they are covered in the following subsections: 1) Student mentoring/tutoring 2) Dynamic systems and agent-based modeling 3) Design of instruction and 4) Games, motivation and the Magic Circle.

\section{Student Mentoring/Tutoring}

Recently, there have been reports that show the United States is losing its edge in the highly competitive STEM disciplines of Science, Technology, Engineering, and Mathematics. The Nation's Report Card documents a decline in science knowledge among our nation's high school graduates. According to the National Assessment of Educational Progress, the nation's 12th graders are performing significantly lower than what 12 th graders were doing only a decade earlier in 1996 (Grigg, Lauko \& Brockway, 2005). This trend is all the more troubling because the modern world demands a minimum of science literacy of all its citizens. There is also a need to develop a method by which all students are able to learn given that with current inclusion practices the majority of classes include students of all ability levels, varying from low to high.

Peer tutoring might possibly be a way of accomplishing this goal. Serving in the role of tutor could also improve the self-esteem and achievement level of at risk students and those students with disabilities (Fulk \& King, 2001).

There are many different types of peer tutoring that can be utilized in the classroom. Among these are Peer-Assisted Learning Strategies (PALS), Reciprocal Peer Tutoring (RPT), 
and Class wide Peer Tutoring (Grubbs \& Boes, 2009). PALS is utilized mostly for math and reading structured tutoring. Generally, high achieving students are paired with low achieving students. RPT consists of two or more students working together prompting, teaching, monitoring, evaluating, and encouraging. Students will alternate roles for RPT (Grubbs \& Boes, 2009). Class-wide peer tutoring occurs when students are taught by peers who have been trained and are supervised by the teacher (Greenwood, Maheady \& Delquadri, 2002).

When individuals work together in order to understand a particular phenomenon, they often have to justify their explanations to themselves and to each other. By doing this the individuals involved learn from each other. According to Ploetzner, Dillenbourg, Praier and Traum (1999) there are five levels of interactivity related to setting:

1. Explaining to oneself: this type of self-explanation can be either out loud or silent.

2. Explaining to a passive and anonymous listener: this type of explanation occurs when the individual is explaining something to someone they do not known and who only listens.

3. Explaining to a passive listener: in this case, the individual explaining knows the person who is just listening.

4. Explaining to someone who responds in a constrained way: in this case the listener may only state that they understand or do not understand with no explanation as to why or why not.

5. Mutually explaining: in this case two individuals are explaining a concept to each other and share understanding.

Of these five levels of interactivity, level 5 occurs most frequently within cooperative learning settings. In problem-based learning settings where students are working in collaborative groups they must work together to come to a conclusion about the solution to the problem. 
While engaging in this process self- and mutual-explanation come into play and significant learning can take place. To date the available research on peer tutoring and mentoring involves public service groups such as Big Brother and Little Sisters and individuals from various careers who enter the secondary classroom as mentors to high school students. Converse and Lignugaris/Kraft (2009) investigated the impact of a school-based mentoring program on incidences of office referrals, absences and school attitude. Participants in that study were only at-risk students who had not been identified and placed on an Individualized Education Plan and the mentors consisted of faculty and staff from the school. These at risk students did benefit from the program and an increase in the behaviors that were targeted could eventually have an impact on learning, however, this was not a part of that study. Herrera, Kauh, Cooney, Grossman and McMaken (2008) examined the efficacy of high school students mentoring elementary and middle school youth. This study suggested that high school students have more structured training and support in order to be successful in this capacity. There is little research available having to deal with classroom practice involving peer tutoring/mentoring.

\section{Tell and Practice and the Alternatives}

In the past the predominant type of instruction, specifically in the content areas of science and mathematics, has been 'tell and practice'. Schwartz, Chase, Oppezzo and Chin (2011) describe tell and practice ( $\mathrm{T} \& \mathrm{P})$ as an instructional method where teachers explain (tell) a concept and then have students practice using or applying that concept. It is a very convenient and efficient way to deliver large amounts of knowledge. However, T \& P may not help students learn the deep structure of some content very effectively. Specifically, if students are given or shown the end product of a problem posed within the content too soon it may short cut the need to find a deeper understanding of the structure described within that knowledge (Schwartz, 
Chase, Oppezzo, \& Chin, 2011). With T \& P, students may be able to immediately understand a particular problem but not be able to extend that understanding to a novel situation. There are alternatives to $\mathrm{T} \& \mathrm{P}$ that use some forms of guided discovery such as problem-based learning, project- and design-based activities and the use of models and simulations.

When students are accustomed to T \& P practices they tend to memorize the details of solving problems within the content (equations, etc.) without internalizing the deeper conceptual meaning. When given a new problem they will tend to apply the steps they have used with the familiar problem in order to solve the new problem because they recognize familiarities within that problem. If these familiar steps cannot be used to solve the problem, frequently the learner will not understand how to begin to find a solution (Catrambone, 1998). Instead of focusing on the individual separate steps in solving a problem it can be beneficial for the learner to group the steps into smaller tasks. In doing this, it is more likely that the learner will be able to integrate prior understanding with the new knowledge for deeper understanding. According to Catrambone (1998), a learner will be able to more effectively utilize self-explanation and assimilate new knowledge with prior knowledge if the learner can perform these tasks or steps in relatively small pieces.

\section{Dynamic Systems and Agent-Based Modeling}

There has also been a documented downward trend in conceptual reasoning, scientific investigation, and practical reasoning skills beginning in the middle grades (Grigg, Lauko, \& Brockway, 2005). Modeling and simulation software might be a possible solution to this problem by aiding students in using critical thinking and reasoning skills to see the future implications of various solutions to real world scenarios. However, programming can prove to be an obstacle for teachers (and even students) to use in the classroom (Ahern, 2009). By using 
StarLogo this problem can be bypassed because the software is extremely easy to use with a drag and drop puzzle piece format (Ahern, 2008a). Models can be programmed and altered within the StarLogo software and various outcomes can be observed. Using StarLogo, studentstudent and student-teacher collaborative discourse can take place and deeper understanding of the content can occur (Ahern, 2008b).

Serendipity is a project that uses dynamic systems modeling (via StarLogo) and teacherdeveloped models to encourage epistemic discourse in the classroom. The real barrier is that teachers and students alike can become caught up in the actual programming and think of it as a means to an end and the ability to contextualize the content can be lost (Ahern, 2009). Various methods of peer tutoring when used in conjunction with dynamic systems modeling software could be very useful in the classroom with helping learners to internalize meaning of difficult content.

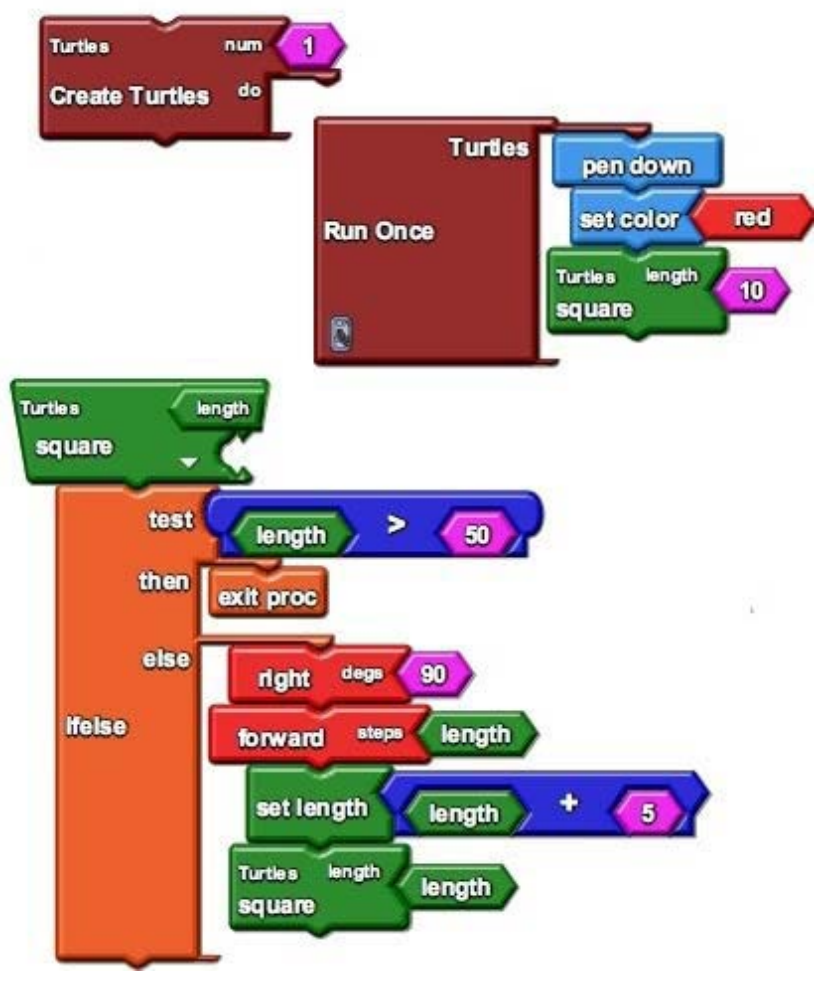

Figure 1. StarLogo puzzle pieces for use in programming (Ahern, 2008) 
The Adventures in Modeling Project at MIT introduces participants to the designing, creating and analyzing their own complex systems models and simulations using StarLogo (Klopfer, Colella \& Resnick, 2002). In these workshops participants (teachers and students) work together collaboratively to design and create their own agent-based models with StarLogo. The design of the workshop is collaborative in a fun and exciting environment in which participants work together. Adventures in Modeling is unique in that students who do not normally have the opportunity to do anything other than explore models and simulations actually are provided with the time and means to create their own. The design of these workshops also lends itself well to whole class instruction. Due to the fact not all participants have access or the time to create complex dynamic systems, the workshops also provide opportunities to start off with existing models, which can be altered and experimented with for possible outcomes. Various models are available for the participants to work with including epidemic and predatorprey models (Klopfer, 2003). There is little research that looks at the use of mentors trained in a specific tool that can support the curricular goals of the classroom. As shown in Adventures in Modeling the focus is on learning the actual software and model building but not as a support mechanism for teaching the underlying concepts of the model.

\section{Design of Instruction}

Elaboration theory describes a process for designing instruction that is used quite often by in-service K12 educators. The process emphasizes instruction that moves from simple concepts to the more elaborate. Wilson and Cole (1992) describe eight basic strategies for the use of elaboration theory in designing instruction. Content should have a single organizing structure that demonstrates the objective for the content. This organizing structure can be conceptual, procedural or theoretical. Content should have a simple-to-complex organization. 
This holds true for any content at the K12 level. Content is covered with the sequence beginning with the most basic concepts and developing understanding through the most complex. There should also be a specific sequencing within lessons.

When instruction is designed conceptually the easiest and most familiar content should be presented first. Procedurally, steps should be presented in an ordered sequence. Theoretically, content should be organized from the simple to the complex. Supporting content should be presented directly after the related content. Underlying principals should be taught and mastered before moving to the more complex content. Reviews should be used as summarizers at lesson and unit levels. Synthesizers are used as content organizers and are usually in diagram form in order that learners can visualize the content. Analogies are used to relate the learners' prior knowledge to the new content. Cognitive strategy activators (diagrams, flow charts, etc.) are either embedded within instruction or detached from instruction in that the learner is asked to visualize a concept. Instruction should also involve learner control so that learning is personalized. Reigeluth and Stein (1983) state that instruction is more effective if the learner has control over both content and instructional strategy.

As stated previously, the elaboration theory of instruction tends to be the most often used method for delivery of K12 content across all content areas. Educators first ascertain what the learner's prior knowledge is and design instruction accordingly progressing from the most basic content to the most complex. However, not all educators are willing to give the learner control of content and delivery. Recently this trend is beginning to reverse with the advent of problembased learning scenarios integrated into instructional delivery. 


\section{Games, Motivation and the Magic Circle}

There are three general types of games; trivial, serious and epistemic games. Trivial games are the most basic type of game. Trivial games are purely played for entertainment purpose and do not generally have an educational value beyond learning how to play the game or having fun. Serious games are designed for purposes other than pure entertainment. Serious games tend to have a specific educational purpose such as training or learning how to do something and can sometimes be referred to as edutainment. Epistemic games are games that go beyond edutainment. Learners are immersed in a real world situation while playing the game. According to Shafer (2005), when "learners engage in socially-valued practices toward ends they value - that is, when learners use real tools and methods to address issues they care aboutmotivation and learning tend to follow."

Motivation is an important part of learning. Csikszentmihalyi (1990) defines flow theory as a method for understanding and implementing motivation. Flow theory requires a perfect balance between challenge and frustration. The end goal becomes so clear that any hindrances disappear. The learner becomes completely involved in an activity by being provided with a challenge, setting goals, having structured control and being provided with clear feedback. If the learner is in complete "flow state" there is complete motivation. Games foster play and produce a state of flow, therefore increasing learning and fostering motivation.

According to Houser and Deloach (1998), there are 7 basic requirements for creating a learning environment:

1. High intensity of interaction and feedback

2. Specific goals and established procedures

3. Motivation 
4. Continual feeling of challenge that is not so hard that it produces frustration or too easy that it causes boredom

5. Provides direct engagement so that the learner experiences the environment and is always working on the task

6. Provides tools that fit the user and task so that they aid and do not distract

7. Distractions and disruptions are avoided in order not to disrupt the subjective experience When these requirements are met by a game-like environment the learning in the play is masked.

While in play we can freely do as we please with little or no consequences. Huizinga (1955) states that play is "a free activity standing quite consciously outside 'ordinary' life as being 'not serious,' but at the same time absorbing the player intensely and utterly." This is the Magic Circle where that player can risk, explore and think without consequence (Salen \& Zimmerman, 2004). Any time spent in the magic circle is time spent away from everyday life and the surroundings.

The Magic Circle can be very instrumental in students' learning. Many of today's learners feel the pressure to succeed and are very concerned with whatever grade they might attain on a particular activity. Within the Magic Circle the learner realizes that it is permissible to risk and the possibility of failure is something that can be overcome quite easily because within the Magic Circle they can try again as much as they'd like. It is ok to fail. When the learner is permitted to escape the fear of risk and failure the opportunities for learning greatly increase.

There are four key attributes that educational games must include (Lepper \& Malone, 1987)

- They must introduce a challenge

- They should create sensory and cognitive curiosity within the learner 
- The learner should feel a sense of control through intrinsic feedback provided through the game

- The game should use fantasy to reinforce the instructional goals and to simulate the prior interest in the learner.

When these four requirements are met, games foster play, which produces a state of flow, which increases motivation, which leads to and supports the learning process. Games have distinctive features from other planned activities and are easily adaptable for use in the classroom (Klopfer, Osterweil, \& Salen, 2009). Games must:

- Have the requirement to try. All actions within the game are well defined and require the player to make some sort of move.

- $\quad$ Provide the opportunity to imagine. Strategy must be employed in order to make a move within the game. Having to employ strategy means that imagination and creativity must also be used. Players must consider the current state of the game play and use strategy, imagination and creativity to make their next move. Prior experience within the game influences the game play.

- Provide the opportunity to experiment. Players can imagine what their next move might be and experiment with the "what if" of the game play and learn from experience.

- Have the possibility of failure. The best thing about playing a game is that within game play it is ok to fail. Flaws and failure are acceptable within the game itself.

- Game play is iterative. There is always another chance to try again within the game after a player fails. The game board is always changing and the player can fail and try again as much as they would like to. 
- Game play is recursive. Every action within the game is built on prior actions within the game play. The game changes in response to every action taken by the players within the game.

\section{Achievement and Motivation}

Educators have been interested for a very long time in fostering student motivation because of the link between motivation and learning activities (Beesley, Clark, Barker, Germeroth, Apthorp, \& Mid-continent Research for Education and Learning (McREL), 2010). If students are not motivated, they also will not be completely engaged in the learning activities. When students are engaged, they are more likely to feel connected to their learning environment, which in turn will stimulate effort and persistence in the curricular tasks. Once students devote extra effort to learning and also concentrate on processing information they remain actively involved with the learning tasks even if those tasks become challenging or difficult. Student engagement is linked to achievement because when students are engaged they are doing the work necessary for learning. Dotterer and Lowe (2011) state that school engagement (both psychological and behavioral) facilitates the link between classroom setting and academic achievement for students without previous achievement difficulties. However, for students who had experienced previous achievement difficulties, classroom setting was related to behavioral engagement, but not psychological engagement. If a student is only cognitively engaged and thinking deeply about a particular learning task, but is not engaged behaviorally, the learning goals may not be accomplished. The opposite is also true. When a student is only behaviorally engaged, that student might seem to be fully concentrating on completing the task but if he/she is not thinking deeply they are only going through the motions of learning (Beesley, Clark, Barker, Germeroth, Apthorp, \& Mid-continent Research for Education and Learning (McREL), 2010). 
Because games tend to increase engagement thereby leading to increased motivation, game-like learning environments are a possible way to increase learning outcomes.

\section{Game-like Learning Environments}

Learning with games is similar to learning with many other types of media (computerbased presentations, textbooks, etc.). Learning depends on the cognitive processing of the learner during the course of learning. Although a game format can increase learner motivation this does not always lead to learning in a meaningful way. The learner must also attend to the relevant content information and be able to meaningfully organize that material cognitively while integrating the new knowledge acquired with prior knowledge. If the learner can accomplish this it will lead to long-term memory of the instructional material. Since simply playing a game will not accomplish this, the instructional methods for accomplishing this can be embedded within a game-like environment. It is necessary to balance game-play and instructional features in an appropriate way in order to promote cognitive processing (Mayer \& Johnson, 2010). Mayer and Johnson (2010) also argue that using instructional methods that encourage reflection while learning can increase processing the material cognitively. The challenge is to design game-like learning environments that will incorporate reflection within game-play that will not disrupt the flow of the game or the learner's sense of control.

\section{Summary of Literature Review}

The rationale of this chapter was to provide a review of the literature that dealt with 1) Student mentoring/tutoring 2) Dynamic systems and agent-based modeling 3) Design of instruction and 4) Games, motivation and the magic circle. The literature review discussed the various methods of peer tutoring. I also discussed five levels of interactivity related to setting that are involved with learners justifying explanations to themselves and to others. Tell and 
practice $(\mathrm{T} \& \mathrm{P})$ is the typical instructional delivery method used in classrooms today.

However, instead of using $\mathrm{T} \& \mathrm{P}$ educators can move towards more problem-based learning and discovery and inquiry methods to better help the learner adjust to novel scenarios in the classroom. In addition to this, if the learners can break down problems and explain them to themselves or others they are more likely to acquire the new knowledge or skill. The literature review discussed dynamic systems and agent-based modeling in relation to increasing critical thinking and reasoning skills to see the future implications of various solutions to real world scenarios. Serendipity and the use of the program StarLogo was discussed in relation to helping learners internalize the meaning of difficult content. The literature review discussed the elaboration theory of instruction and how it tends to be the most often used method for delivery of K12 content across all content areas. However, an essential part of elaboration theory deals with the teacher being willing to give control of the content and delivery to the student and this is not something that all teachers are comfortable doing. The link between motivation and class engagement was also discussed. Research shows that the learner must be involved behaviorally as well as cognitively in order to foster motivation and engagement (Beesley, Clark, Barker, Germeroth, Apthorp, \& Mid-continent Research for Education and Learning (McREL), 2010). The literature review also discussed games, motivation and the magic circle in relation to the three general types of games; trivial, serious and epistemic games. The concept of design of curriculum using game-like learning environments was discussed along with the importance of designing game-like learning activities that can increase cognitive processing of content while encouraging game-play and learner control. Although there is published research discussing the instructional design of activities using game-like environments in addition to research on the use of simulations in content delivery, I have not been able to find research dealing with the use of 
student mentors in game-like learning environments using simulations for instructional delivery of content.

Instructional design in the middle school science classroom can be complicated when covering difficult content while at the same time motivating all levels of learners. When the use of computer programming is involved with content delivery it can cause a disconnect between using the program and also learning the content by focusing the learner on the technological issues and not the actual content. By using student mentors in this type of scenario, this "Siren's Call" can be channeled because of the dynamics of self- and mutual-explanation and how learning outcomes can be enhanced. The following chapter covers in detail the methodology that was used for the study. This chapter will include information on how the participants were selected, data collection procedures, and data analysis. 


\section{Chapter III: Methodology}

\section{Overview}

The purpose of this study is to investigate the use of student mentors in conjunction with a game design metaphor for instructional delivery of middle school science content. An introductory biology unit was designed using a game-design metaphor. The different areas within the content were arranged as levels:

- Level 1 dealt with the cell,

- Level 2 dealt with body systems,

- Level 3 involved collaborative presentations of Levels 1 and 2, and

- Level 4 was the programming of a simulation of an epidemic using StarLogo software. To achieve a game-like feel the unit was wrapped in a metaphor such as that in Chutes and Ladders. Each level in the unit was traversed using a ladder or a chute. Each student had to master a particular level by "scoring" a minimum percentage on a non-graded exit ticket for that level in order to progress to the next level.

During Level 4 student mentors aided in instruction in order to help steer the students away from the "Siren's Call" so that they could interact with the content using the prior knowledge mastered during Levels 1-3.

The research questions to be addressed were:

RQ1: Can science content be designed and successfully delivered instructionally using a gamelike learning environment?

RQ2 - Will the use of student mentors/assistants help direct and maintain the flow of the class away from the technological issues toward the necessary learning outcomes while also increasing 
the science content understanding acquired by the mentors themselves while also increasing class and student engagement?

\section{Research Hypothesis}

For this research project, peer tutors/ mentors who had been trained in the use of StarLogo were utilized to help bypass the disconnect between the technology programming and the meaning of the actual content. It was hoped that the use of peer tutors/mentors would improve the ability of the learners to grasp in depth concepts through inquiry in whole class instruction.

The research hypotheses for the first research question (RQ1) are:

$\mathrm{H}_{0}$ : There is no statistically significant difference between the pre-test and post-test scores for all learners during the study.

$\mathrm{H}_{\mathrm{a}}$ : There is a statistically significant difference between the pre-test and post-test scores for all learners during the study.

The research hypotheses for the second research question (RQ2) are:

$\mathrm{H}_{0}$ : There is no statistically significant difference between the pre-test and post-test scores for the trained mentors during the study.

$\mathrm{H}_{\mathrm{a}}$ : There is a statistically significant difference between the pre-test and post-test scores for the trained mentors during the study.

\section{Methodology}

\section{Participants}

For the study the learners were 13-14 years of age and enrolled in 8th grade at a midAtlantic middle school. The study involved 165 students. The learners will be able to apply skills from the STEM disciplines (science technology, engineering and math) to solve a real 
world problem. Classes at this middle school were divided into 45-50 minute class

periods. For convenience, participants involved in the study consisted of the entire $8^{\text {th }}$ grade enrolled at the school. All data gathered from participant resources was collected with explicit permission from the participants and in full compliance with Institutional Review Board (IRB) guidelines. As per current inclusionary practices, the teacher had all students as members of the classroom. The range of student ability levels included severely mentally impaired (very low level autistic), identified behavior disorder, and academically gifted. Students who volunteered as "experts" to act in the capacity of student mentors were students who had demonstrated an acceptable level of expertise with the material. All students were instructed in proper pedagogical techniques that can be used when dealing with helping their fellow students. "Trained" experts/mentors consisted of students who had volunteered to attend voluntary programming meetings during which they learned to program simulations using StarLogo. Volunteers were identified via participation in a poll published to the school's classroom management system. "Untrained" experts/mentors consisted of students who had developed expertise using StarLogo either during class sessions or outside of class on their own.

\section{Research Design}

The design for this study will be a naturalistic mixed method design conducted in an intact $8^{\text {th }}$ grade science class broken into 6 class periods. The content for the unit was delivered using a gaming metaphor with student prior experience with the content informing the design of the unit (current state of play). The unit addressed introductory biology topics, specifically beginning with the cell and body systems and advancing to the dynamics of an epidemic.

The content was viewed as different levels of a "game" (Appendix B) with a set of rules (Appendix C). The beginning level (Level 1) dealt with animal and plant cells. When students 
mastered the content of that level, they could advance to the next level (Level 2)

concerning body systems. The first part of Level 1 dealt with the lowest level of Blooms Taxonomy (remembering/identifying) and participants self-selected various means of accomplishing a means of dealing with plant and animal cells. For the second part of Level 1 students advanced to the next level of Blooms (understanding) and self-selected a means of comparing/contrasting plant cells vs. animal cells (Appendix D). Exit tickets/polls were administered at the end of each level of instruction in order to gauge learning and understanding.

Participants were required to score at least an $80 \%$ before they could advance to the next level. Participants could retake the exit ticket/quiz until the required score was received (Appendix E). The same process was followed for Level 2 (body systems). Once Level 2 was mastered (Appendix F), participants advanced to Level 3, which involved utilizing content covered in Levels 1 and 2 to apply, synthesize and analyze/evaluate (upper levels of Blooms). They used what they had learned during Levels 1 and 2 to construct a presentation of their own choosing. As in a game, once the content for Level 3 was mastered (Appendix G) students could advance to Level 4,which corresponded with the highest level of Bloom's Taxonomy concerning the dynamics of an epidemic. During level 4 the students programmed a simulation of an epidemic using StarLogo software.

A pretest was given at the beginning of the unit to determine current knowledge and the results were used to inform the design of each level of instruction (Appendix H). Any questions that were on the pre-test but not the post-test were not included in the scores used for data analysis. The pretest also did not count towards the students' grades and was only used to gauge current levels of knowledge. Scores on exit tickets/polls were also not used to determine student grades on the unit but were only used to determine advancement to the next level. Level 4 
(programming the epidemic simulation) was not graded in order for the students to experience the game within the "magic circle." A post-test was given after the final level dealing with epidemics and the scores were analyzed and compared to the pretests in order to determine the success of instruction based on a gaming metaphor (Appendix I).

In order to determine the success of using mentor students, the activities were designed using a game-like learning environment with the mentors in the classroom helping other students as needed. Individual student (Appendix J) and class engagement (Appendix K) checklists were analyzed and compared. Non-biased observers were chosen from the school faculty, student teachers and the researcher's doctoral advisor for completion of checklists. Additionally, video was taken at different times during the project and analyzed for levels of engagement. For the videos, levels of engagement were determined by counting the number of student-student and teacher-student interactions. Field notes were taken by outside observers and the classroom teacher and analyzed. A pretest was given at the beginning of the unit to determine current knowledge and the results were used to inform the design of each level of instruction. Periodically throughout the study, exit tickets/polls were administered in order to track learning over time throughout the project. A post-test was given after the final level dealing with epidemics in order to determine the success of instruction based on a gaming metaphor. Pretest/posttest scores and exit tickets/polls for mentor students were compared and analyzed in order to determine if "teaching" other students had helped them to deepen their understanding of the content.

\section{Data Sources}

Various data sources were used for this study (Appendix L). For Research Question 1, a pre-test was given at the beginning of the unit in order to ascertain what the learners' levels of 
understanding were. Exit tickets were used at the end of both level 1 and level 2 in order to insure mastery before moving to the next level. A presentation rubric was used at the end of level 3 in order to provide guidance to the students regarding what information they should be familiar with. Field notes and video were taken at various intervals throughout the study in order to observe and note learner interactions and engagement patterns. At the end of the unit a posttest was given to gauge levels of understanding. For Research Question 2, checklists dealing with student/class engagement, field notes, and video were used in order to analyze levels of student/class engagement and interactions.

\section{Procedure}

The unit of study was covered in relation to the West Virginia Content Standards and Objectives for biology (Appendix A). A pre-test on the material was given to ascertain the prior knowledge of the students (Appendix H). Any questions that were on the pre-test but not the post-test were not included in the scores used for data analysis. Seating in the classroom consists of science tables in groups of two, which lends itself naturally to groups of 3-4 students. Each group of students was given a packet of materials covering what all of the levels consisted of and a description of the "game" (Appendix C). Groups had access to textbooks and a 30-laptop mobile laptop lab in the classroom for the duration of the project. For Level 1, students worked together to research and depict in a way of their own choosing terms related to cell biology and the parts of the cell. They were also to become familiar with photosynthesis, respiration and fermentation. As an additional aspect of the level students also needed to demonstrate and understanding of how the parts of the cell worked together. They were also to discuss, compare, or contrast what they had learned in the level. The group could choose whatever method for accomplishing this that they thought was sufficient. Once all members of the group felt ready 
they were to take the exit ticket/quiz (Appendix E) via the course management web site that the school uses. When students were done with the exit ticket they would come to the teacher and check their grade (immediate feedback) and if they had not attained an $80 \%$ they were to retake the exit ticket until they attained at least an $80 \%$. Students could prepare for the retake as they saw fit. Some students would review their group's materials for that level or just review and discuss with members of their group. The stipulation was also made that the group could not progress to the next level in the game until all members had passed with a minimum score of $80 \%$ on the exit ticket. Once all members of the group attained at least an $80 \%$ on the exit ticket for that level the group could progress on to the next level.

For Level 2, students familiarized themselves with the body systems. The second level followed the same organization as the first level. Once students were familiar with the basics of the body systems they were to demonstrate an understanding of the interactions of the body systems by selecting a way to present that information (PowerPoints, diagrams, etc.). When the group members felt ready and that they had mastered the material in level 2 they could take the online exit ticket/quiz (Appendix F). Once all members of the group "passed" with at least an $80 \%$ they could move on to Level 3. If all members of the group did not attain an $80 \%$ they could go back to their tables and help each other to review the material and retake the exit ticket until the $80 \%$ was reached.

Level 3 of the "game" involved a group summary presentation of materials covered in both level 1 and 2. Groups could take everything they had produced in levels 1 and 2 and combine them into one presentation to present to the rest of the class. The Level 3 presentations acted as a review for the students before they could progress to Level 4 . Level 4 was conducted as a whole class experience where every student had his or her own laptop with which to work. 
The teacher used the desktop computer in the classroom that was connected to the virtual whiteboard while leading the students through the steps of constructing a simulation of an epidemic in StarLogo. As the teacher worked with the students to build the epidemic model, trained and untrained experts/mentors would help other students in the room who seemed to be having difficulties with the programming. While programming the model/simulation whole class discussion were held concerning how epidemics work, ways that the program could be altered to better approximate "real life," etc. Classes also were able to construct dynamic bar graphs within the program that changed as the model ran. After completion of Level 4, all students took a post-test, which consisted of questions taken from Level 1 and level 2 exit tickets/quizzes (Appendix I).

\section{Limitations}

Limitations involved in the research were related to participants, overall methodology, data sources, data collection procedures, and data analysis procedures. Some participants were not given parental permission/consent to participate or did not turn in their own assent forms. These students were not included in any data collection (checklists, video, etc). The methodology was complicated by time constraints and delays involving interruptions to the school day and changes to the school calendar concerning assemblies that were scheduled that had not previously been scheduled, etc. These circumstances were dealt with as they arose by making adjustments to the unit timeline and modifications to instruction. It was anticipated that misunderstanding of criteria or bias of observers involving the checklists might affect data sources and data collection procedures. These limitations were dealt with by conferencing with observers ahead of time on the use of the checklists and various aspects of the criteria were clarified for them. All questions and concerns of the observers were identified and dealt with 
prior to observations being conducted. When at all possible observers who were utilized during the candidacy proposal research were also included in this study. The number of outside observers was kept at a small number and the same observers were used for all observations in order to promote consistency of observation. Data analysis was accomplished using HyperResearch software in order to maintain consistency of analysis.

\section{Summary of the Methodology}

This chapter presented the methodology and procedures used in this study. An ethnographic study was conducted to investigate the use of student mentors in conjunction with a game-like learning environment for instructional delivery of middle school science content. The participants in the study were 13-14 years of age and enrolled in 8th grade at a mid-Atlantic middle school. The study involved approximately 165 students. An introductory biology unit was designed using a game design metaphor. Student mentors were involved in the final portion of the game designed curriculum in order to see if they would be able to help steer the learners away from the Siren's Call of the instrument in order to concentrate on the learning outcomes. The following chapter provides a detailed description of the statistical and narrative analysis of the data collected. 


\section{Chapter IV: Findings}

\section{Overview}

The purpose of this study was to investigate the delivery of science content using a gamedesign metaphor that incorporates student mentors in the classroom. The aim of this chapter is to provide a detailed description and analysis of the data collected during the course of the study in which the learners completed an introductory biology unit designed using a game based metaphor. Particular attention will be given to the use of student mentors during the final stage of the unit where learners programmed an epidemic using StarLogo. The effect of the design and implementation of the unit on the learning outcomes of the mentors will also be discussed. The data collected in this research was to address the following questions:

RQ1: Can science content be designed and successfully delivered instructionally using a game-like learning environment?

RQ2 - Will the use of student mentors/assistants help direct and maintain the flow of the class away from the technological issues toward the necessary learning outcomes while also increasing class and student engagement?

This chapter will be divided into three main sections: 1) modes of data analysis, 2) demographic data, and 3) major findings.

\section{Modes of Data Analysis}

In this study, each research question was addressed through five different methods.

Research Question 1, dealing with the success of the game-like instructional delivery method, utilized a pre-test vs. post-test methodology. Learners were given a pre-test prior to the beginning of the unit and were also given a post-test following the final level which consisted of the activity of programming an epidemic using StarLogo. A paired-samples t-test was conducted 
to compare all learners' pre-test scores and post-test scores. Research Question 2 was addressed through various methods that included checklists, field notes (completed by both teacher and outside observers), and video. Field notes were coded and analyzed qualitatively using HyperResearch software (ResearchWare, Inc., 2011). Video was examined and analyzed utilizing HyperTranscribe software (ResearchWare, Inc., 2011). A paired-samples t-test was conducted to compare mentors' pre-test scores and post-test scores.

\section{Demographic Data}

The sample for this study consisted of learners 13-14 years of age and enrolled in 8th grade at a mid-Atlantic middle school. The study involved 165 mixed gender students. The learners were able to apply skills from the STEM disciplines (science technology, engineering and math) to solve a real world problem. Classes at this middle school were divided into 45-50 minute class periods. For convenience, participants involved in the study consisted of the entire $8^{\text {th }}$ grade enrolled at the school. All data gathered from participant resources was collected with explicit permission from the participants and in full compliance with Institutional Review Board (IRB) guidelines. As per current inclusionary practices, the teacher had all students as members of the classroom. The range of student ability levels included severely mentally impaired (very low level autistic), identified behavior disorder, and academically gifted. Students who volunteered as "experts" to act in the capacity of student mentors were students who had demonstrated an acceptable level of expertise with the material ('untrained"). Acceptable levels of expertise with the program were determined in two ways. The "trained" experts/mentors consisted of students who had volunteered to attend voluntary programming meetings during which they learned to program simulations using StarLogo. These volunteers consisted of any students who had answered positively to a poll posted to the school's classroom management 
system. "Untrained" experts/mentors consisted of students who had developed an expertise using StarLogo either during class sessions or outside of class on their own. These students were not required to volunteer to come to any meetings but only work consistently with the program. All students were instructed in proper pedagogical techniques that can be used when dealing with helping their fellow students.

\section{Major Findings}

\section{Research Question One}

Pre-test and post-test results for all participants were input into Excel in order to compare and analyze the results. All students made significant improvement between pre-test and posttest. Period 2 results showed improvement across all students (see Figure 2).

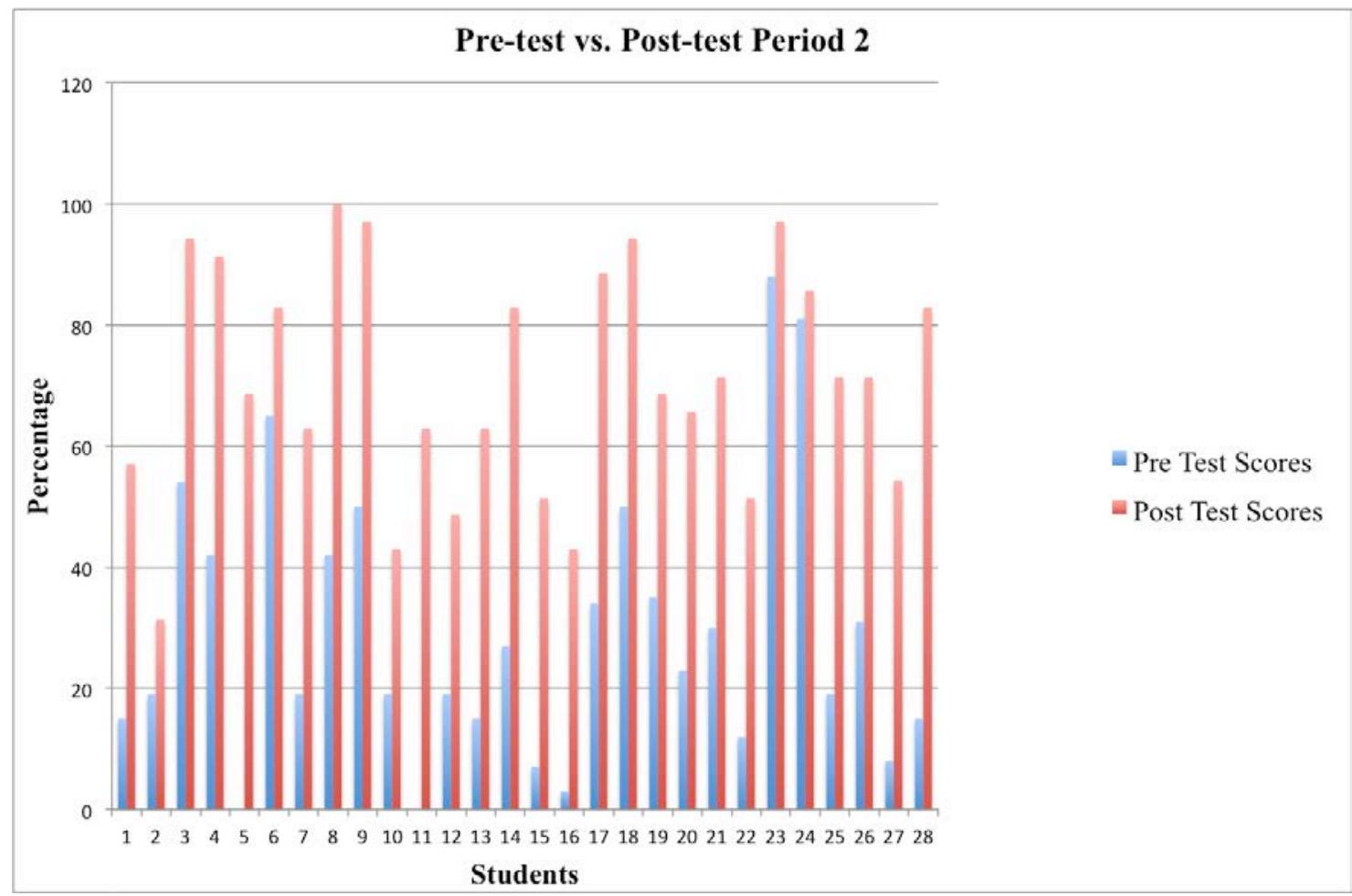

Figure 2. Pre-test vs. Post-test results for Period 2 
Two students in particular in period 2 showed dramatic improvement (students 15 and 16).

Period 3 results showed improvement across all students (see Figure 3).

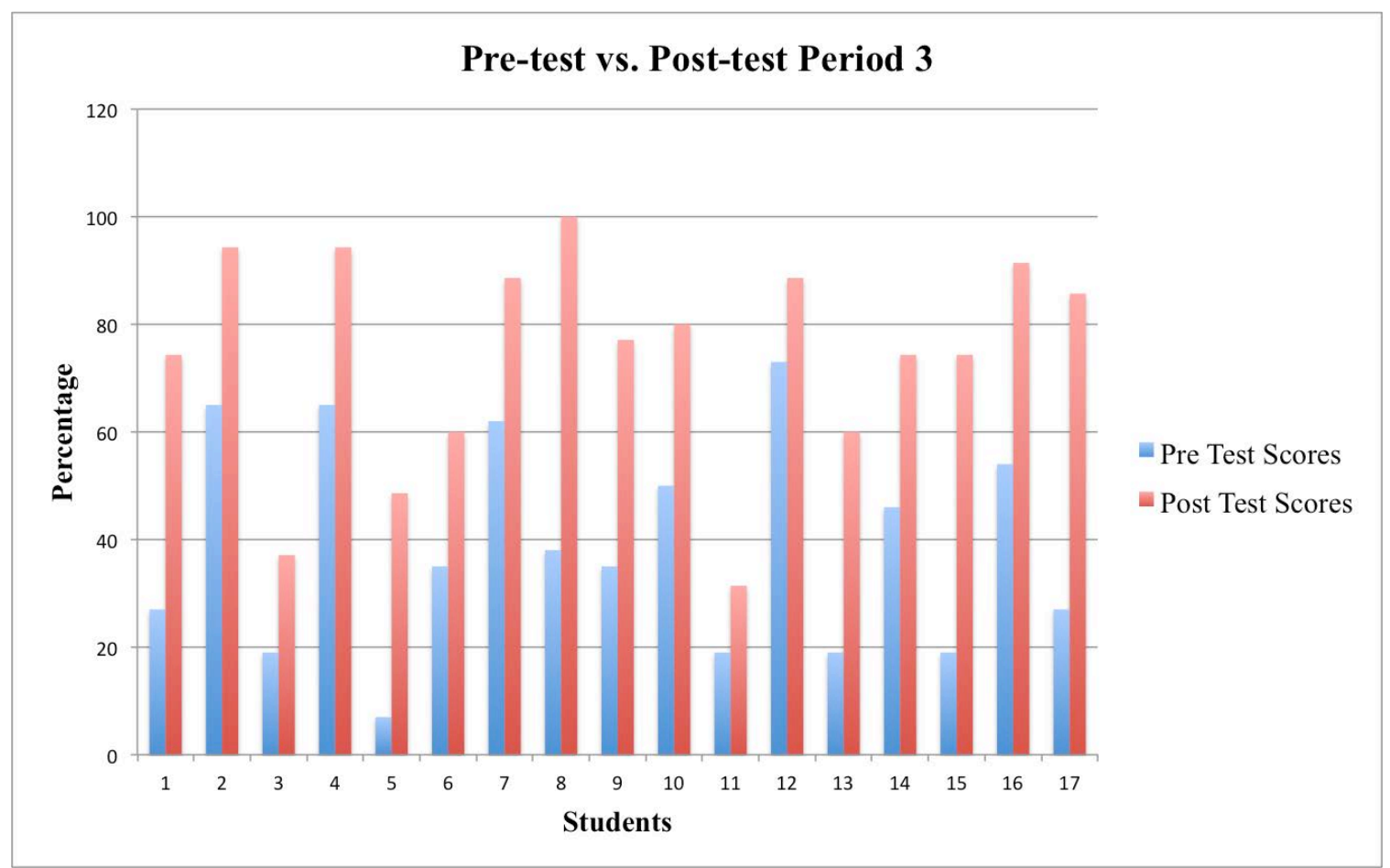

Figure 3. Pre-test vs. Post-test results for Period 3

Period 3 was a much smaller class (17 students) but still showed improvement across all learners with Student 5 showing significant improvement.

All students in Period 4 also showed improvement from pre-test to post-test (see Figure 4). Student 8 improved their score the most significantly. Although Student 14 did not show as significant improvement the score from pretest to post test still increased. Improvement for Student 14 may have not have been as significant because that student had already attained mastery previous to instruction. 


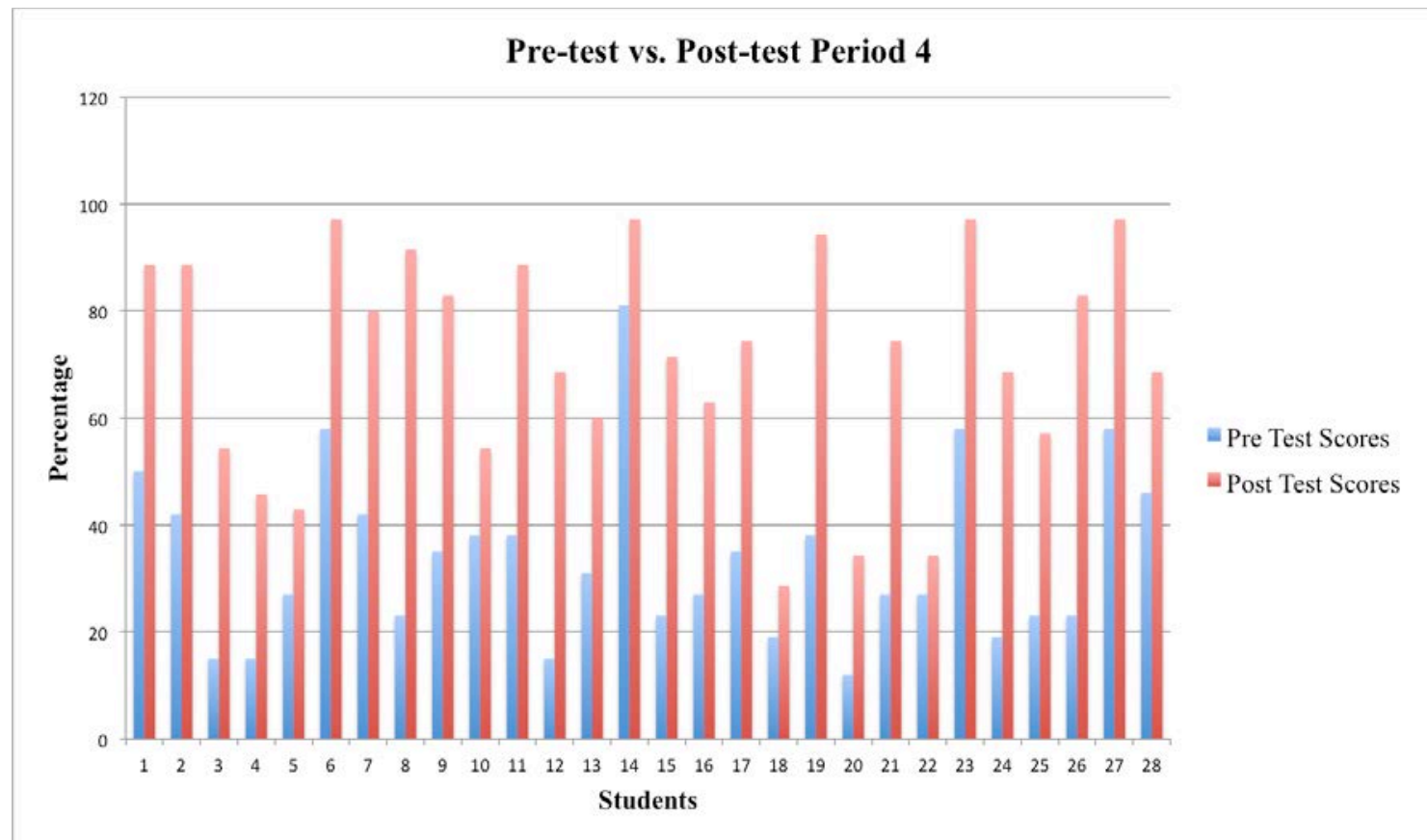

Figure 4. Pre-test vs. Post-test results for Period 4

Just as the rest of the classes, Period 5 still showed improvement across all students (see Figure 5). Student 4, specifically, showed the most improvement.

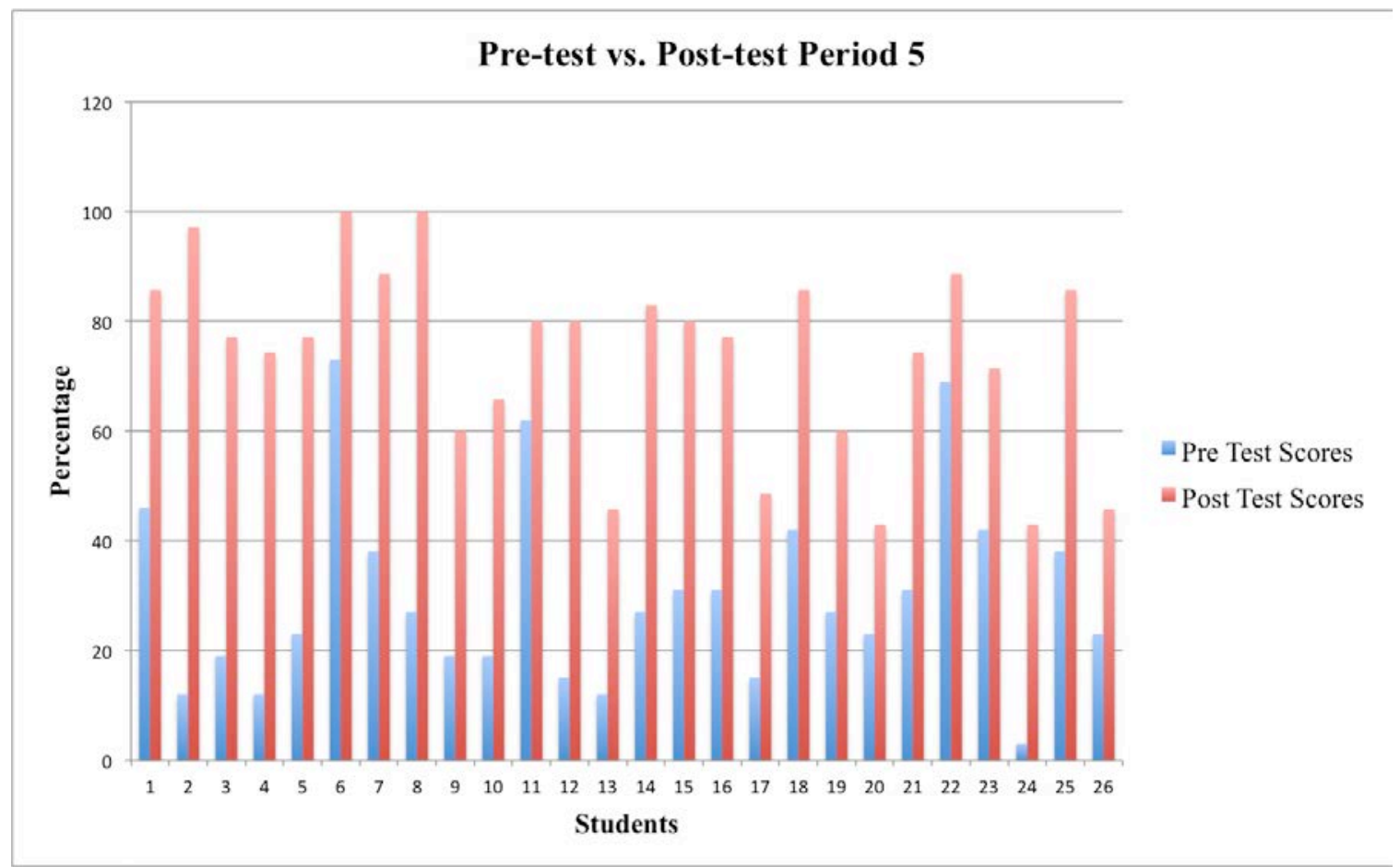

Figure 5. Pre-test vs. Post-test results for Period 5 
Period 6 also showed improvement pre-test to post-test. All students showed significant improvement with the exception of Student 10, but even this student still scored higher on the post-test (see Figure 6). Student 10 most likely had already attained mastery previous to instruction.

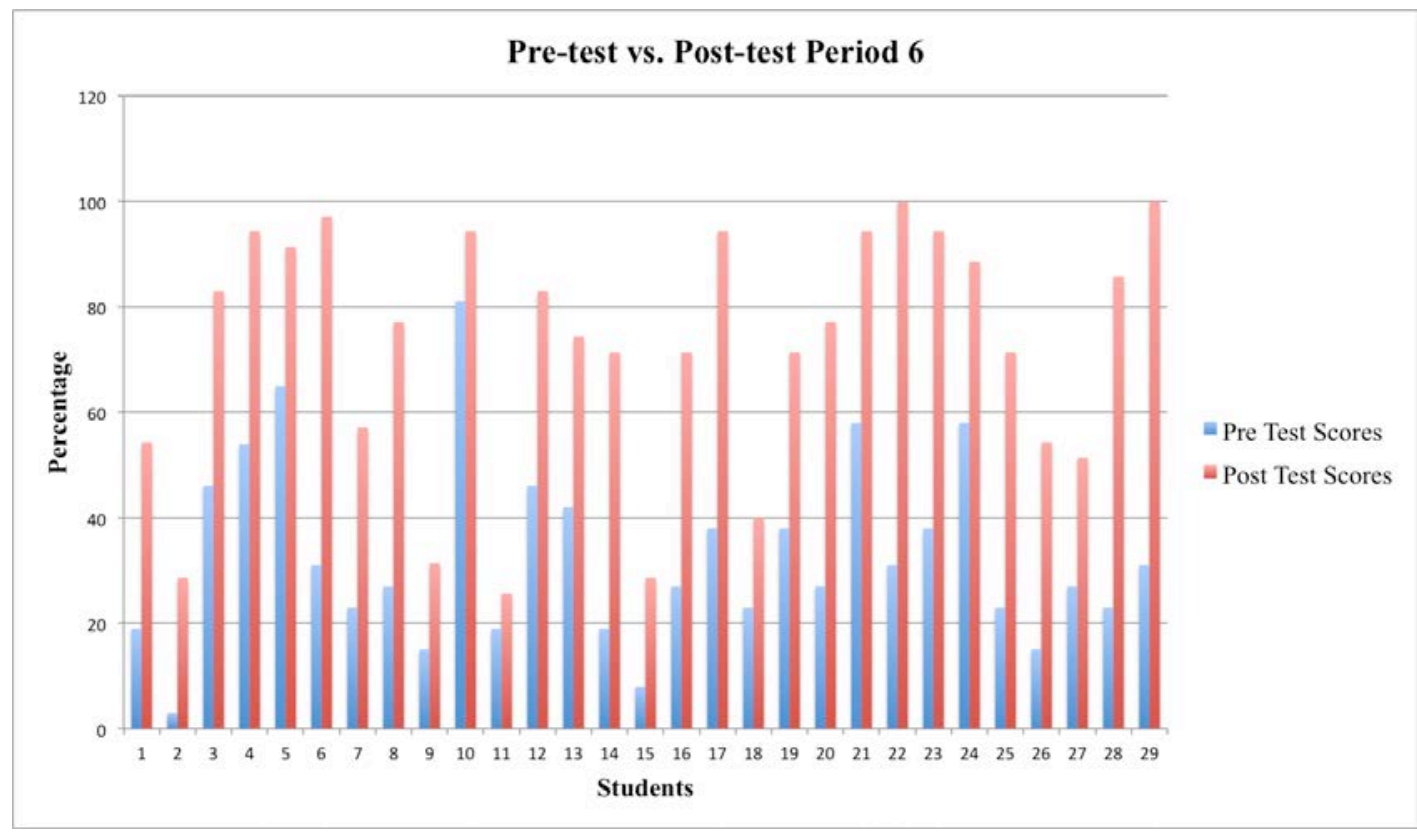

Figure 6. Pre-test vs. Post-test results for Period 6

Finally, all students in period 8 also demonstrated improvement, with a number of students improving their scores greatly (see Figure 7). 


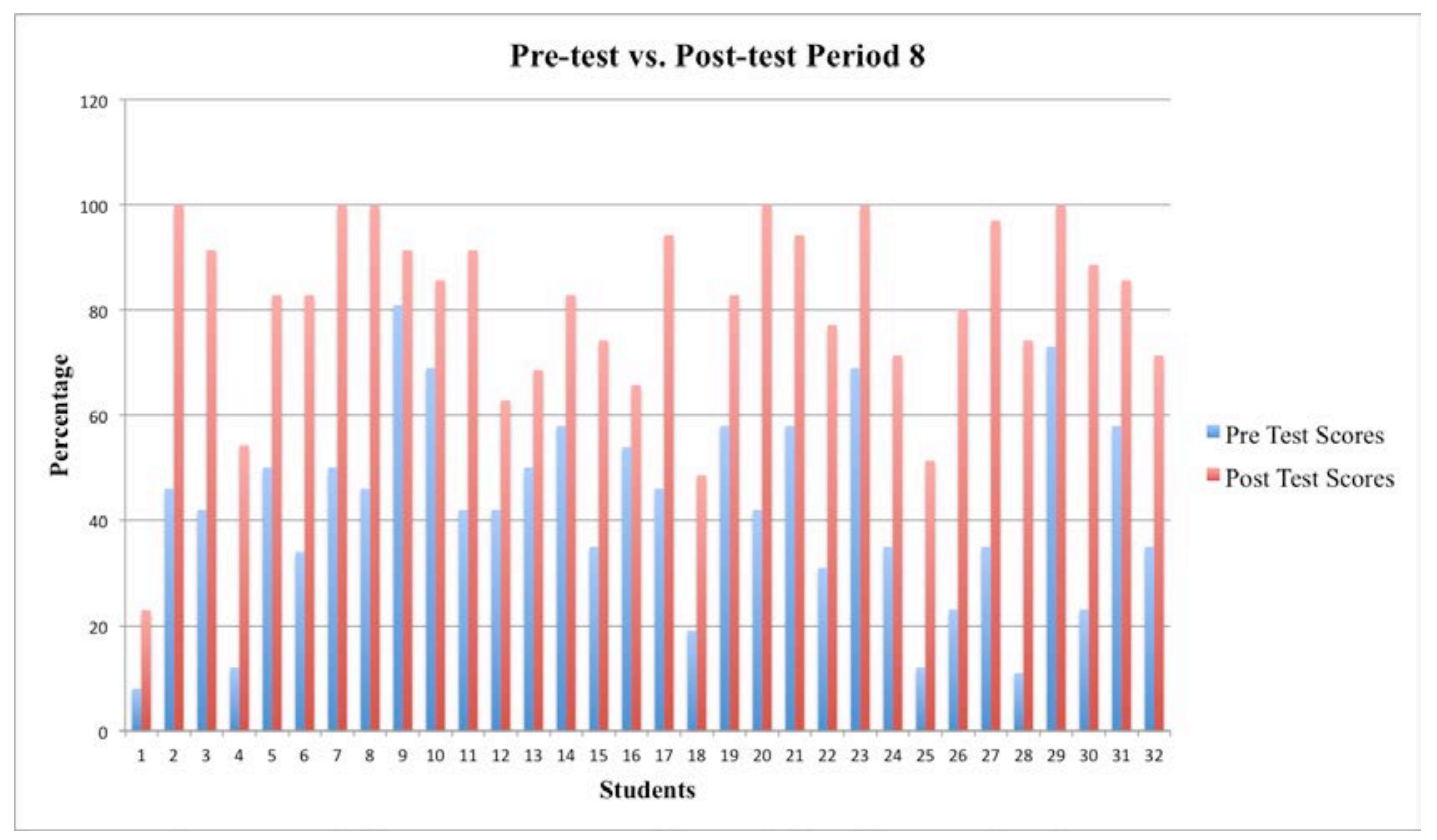

Figure 7. Pre-test vs. Post-test results for Period 8

A paired-samples t-test was conducted using SPSS to compare whether the mean of the differences of each student's pre-test and post-test score was significantly different from zero (Table 1). There was a significant difference in the mean of the pre-test scores and post-test scores $(\mathrm{M}=39.19, \mathrm{SD}=16.03), \mathrm{t}(158)=30.82, \mathrm{p}=.000$. These results indicate that science content can be designed and successfully delivered instructionally using a game-based metaphor. 
Table 1 Pre-test versus Post-test Scores Paired-Samples t-test for All Learners

Paired Samples Statistics

\begin{tabular}{|c|c|c|c|c|c|}
\hline & & Mean & $\mathrm{N}$ & $\begin{array}{c}\text { Std. } \\
\text { Deviation }\end{array}$ & $\begin{array}{c}\text { Std. Error } \\
\text { Mean }\end{array}$ \\
\hline \multirow[t]{3}{*}{ Pair 1} & Post Test Scores & 73.78 & 159 & 20.05 & 1.59 \\
\hline & Pre Test Scores & 34.60 & 159 & 19.05 & 1.51 \\
\hline & \multicolumn{5}{|c|}{ Paired Samples Correlations } \\
\hline
\end{tabular}

\begin{tabular}{llccc} 
& & N & Correlation & Sig. \\
\hline Pair 1 & Post Test Scores \& Pre Test Scores & 159 & .665 & .000
\end{tabular}

\begin{tabular}{|c|c|c|c|c|c|c|c|c|c|}
\hline \multicolumn{10}{|c|}{ Paired Samples Test } \\
\hline & & \multicolumn{5}{|c|}{ Paired Differences } & \multirow{3}{*}{$\mathrm{t}$} & \multirow{3}{*}{$\mathrm{df}$} & \multirow{3}{*}{$\begin{array}{l}\text { Sig. } \\
(2- \\
\text { tailed })\end{array}$} \\
\hline & & \multirow[t]{2}{*}{ Mean } & \multirow[t]{2}{*}{$\begin{array}{c}\text { Std. } \\
\text { Deviation }\end{array}$} & \multirow[t]{2}{*}{$\begin{array}{l}\text { Std. } \\
\text { Error } \\
\text { Mean }\end{array}$} & \multicolumn{2}{|c|}{$\begin{array}{l}95 \% \text { Confidence } \\
\text { Interval of the } \\
\text { Difference }\end{array}$} & & & \\
\hline & & & & & Lower & Upper & & & \\
\hline $\begin{array}{l}\text { Pair } \\
1\end{array}$ & $\begin{array}{l}\text { Post Test } \\
\text { Scores - } \\
\text { Pre Test } \\
\text { Scores }\end{array}$ & 39.19 & 16.03 & 1.27 & 36.68 & 41.70 & 30.82 & 158 & .000 \\
\hline
\end{tabular}

\section{Research Question Two}

Three methods of qualitative methods were utilized to examine Research Question 2.

These methods consisted of examining checklists, video and field notes. Checklists were used to examine both student engagement (Appendix J) and class engagement (Appendix K). The following criteria were used for the checklist with options for levels of Very High, High, Medium, Low, Very Low and N/A (not applicable):

- Positive Body Language 
- Consistent Focus/Time On task/Engagement

- Verbal Participation

- Individual Attention

- Student Interaction

- Fun and Excitement

- Meaningfulness of Work

- Overall Level of Class Engagement

Outside observers volunteered to use the checklist to make observations during different classes. Outside observers consisted of in-service and pre-service teachers at the school and my doctoral advisor. As can be seen from Table 2 overall class engagement levels were Medium (39) to Very High (30) with marks falling predominantly into the High (62) range. For example, Positive Body Language was noticed 10 instances overall by all observers while Student Interaction with Peers was observed 9 times. 
Table 2 Overall Class Engagement Checklist

\begin{tabular}{|c|c|c|c|c|c|c|}
\hline Observations & $\begin{array}{l}\text { Very } \\
\text { High }\end{array}$ & High & Medium & Low & $\begin{array}{l}\text { Very } \\
\text { Low }\end{array}$ & $\mathbf{N} / \mathbf{A}$ \\
\hline $\begin{array}{l}\text { Positive Body Language - Students in } \\
\text { the classroom generally exhibit body } \\
\text { postures that indicate they are paying } \\
\text { attention to the teacher and/or other } \\
\text { students (actively listening, questioning, } \\
\text { etc.) }\end{array}$ & 4 & 10 & 6 & 1 & 0 & 0 \\
\hline $\begin{array}{l}\text { Consistent Focus/Time On } \\
\text { Task/Engagem ent - The class is } \\
\text { focused on the learning activity with } \\
\text { minimal disruptions. Student is engaged } \\
\text { with the current task }\end{array}$ & 2 & 7 & 11 & 0 & 0 & 0 \\
\hline $\begin{array}{l}\text { Verbal Participation - Students are } \\
\text { expressing thoughtful ideas, volunteering } \\
\text { reflective answers, and their questions } \\
\text { are relevant or appropriate to learning }\end{array}$ & 3 & 11 & 11 & 0 & 0 & 0 \\
\hline $\begin{array}{l}\text { Individual Attention - Students in the } \\
\text { class feel comfortable seeking help and } \\
\text { asking questions }\end{array}$ & 6 & 10 & 4 & 0 & 0 & 0 \\
\hline $\begin{array}{l}\text { Student Interaction with Peers-Student } \\
\text { interacts with and offers assistance to } \\
\text { other students instead of asking } \\
\text { questions }\end{array}$ & 8 & 9 & 3 & 0 & 0 & 0 \\
\hline $\begin{array}{l}\text { Fun and Excitement - Students in the } \\
\text { class are exhibiting interest and } \\
\text { enthusiasm and using positive hum or }\end{array}$ & 1 & 7 & 10 & 1 & 0 & 0 \\
\hline $\begin{array}{l}\text { Meaningfulness of Work - The class } \\
\text { finds the work interesting, challenging, } \\
\text { and connected to learning }\end{array}$ & 1 & 8 & 9 & 1 & 0 & 0 \\
\hline Overall Level of Class Engagement & 30 & 62 & 39 & 3 & 0 & 0 \\
\hline
\end{tabular}

Individual Students Engagement Checklists also showed a predominance of marks in Medium to Very High ranges with the largest number falling into the High range. Overall 
Student Engagement was observed as High 143 times by observers.

Table 3 Overall Student Engagement Checklist

\begin{tabular}{|c|c|c|c|c|c|c|}
\hline Observations & $\begin{array}{l}\text { Very } \\
\text { High }\end{array}$ & High & Medium & Low & $\begin{array}{l}\text { Very } \\
\text { Low }\end{array}$ & $\mathrm{N} / \mathrm{A}$ \\
\hline $\begin{array}{l}\text { Positive Body Language - Student exhibits body } \\
\text { postures that indicate he/she is paying attention to } \\
\text { the teacher and/or other students }\end{array}$ & 13 & 24 & 19 & 3 & 1 & 0 \\
\hline $\begin{array}{l}\text { Consistent Focus/Time On Task/Engagement - } \\
\text { Student is focused on the learning activity with } \\
\text { minimal disruptions. Student is engaged with the } \\
\text { current task }\end{array}$ & 14 & 23 & 15 & 5 & 2 & 1 \\
\hline $\begin{array}{l}\text { Verbal Participation - Student expresses } \\
\text { thoughtful ideas, reflective answers, and questions } \\
\text { are relevant or appropriate to learning }\end{array}$ & 15 & 20 & 14 & 7 & 3 & 1 \\
\hline $\begin{array}{l}\text { Individual Attention - Student feels com fortable } \\
\text { seeking help and asking questions }\end{array}$ & 12 & 30 & 11 & 3 & 1 & 4 \\
\hline $\begin{array}{l}\text { Student Interaction with Peers-Student interacts } \\
\text { with and offers assistance to other students instead } \\
\text { of asking questions }\end{array}$ & 19 & 20 & 10 & 6 & 2 & 1 \\
\hline $\begin{array}{l}\text { Fun and Excitement - Student exhibits interest } \\
\text { and enthusiasm and uses positive humor }\end{array}$ & 15 & 16 & 19 & 9 & 1 & 0 \\
\hline $\begin{array}{l}\text { Meaningfulness of Work - Student finds the } \\
\text { work interesting, challenging, and connected to } \\
\text { learning }\end{array}$ & 16 & 10 & 22 & 9 & 1 & 2 \\
\hline Overall Level of Student Engagement & 104 & 143 & 110 & 42 & 11 & 9 \\
\hline
\end{tabular}

However, for student checklists there were also marks in the Low to Very Low ranges. In addition to there being more data involved in this data set because it involved students in individual classes, examining data from different students increased the possibility of a student being observed that typically would not demonstrate on task behavior in class. For example, one 
of the outside observers stated for a student “Off task behavior (playing/hiding another's binder)" and for the same student, "Seems unaware about what is going on around him." This would corroborate observations I made about this student during the year in addition to the fact that this student is on a Student Assistance Plan with modifications accounting for off task behavior. Another outside observer observed a different student in another class, "off task, needs constant reminders to stay on task, group seems unsure about who is doing what, once started work actually gets done - works well with group when focused." This also is in agreement with my observations of this student and others in that particular class over the past year.

Video was also taken of various classes and coded for analysis using HyperResearch. Coding was used that correlated with the criteria on the Student and Class Engagement Checklists. The following coding was used:

- Positive Body Language

- Consistent Focus/Time On Task/Engagement

- Inconsistent Focus/Time Off Task/Not Engaged

- Negative Body Language

- Verbal Participation

- Individual Attention

- Student Interaction with Peers

- Student Non-Interaction With Peers

- Fun and Excitement

- Lack of Fun and Excitement

- Meaningfulness of Work 
- Not Seeing Meaningfulness of Work

All field notes were transcribed into a single document per class period and imported into HyperResearch. Each class was coded and a frequency report was generated. All classes demonstrated increased levels of on task behavior, engagement and peer interaction. The results for each class period were consistent with outside observer field notes and the behavior I am familiar with for those classes.

For Period 2 the Code Frequency Chart showed increased occurrences of Student Interaction with Peers with Meaningfulness of Work and Consistent Focus/Time On Task/Engagement at increased levels also (see Figure 8). This is consistent with the outside observer field notes:

- "Engaging the other students in his group"

- "Motivating them to work on the assigned task"

- "Seems to be a leader in the group"

- "Helping peer, but not 'taking over' his computer"

- "Excited to help other peers, moving around the room to assist others"

- "Provided assistance to others at table" 


\begin{tabular}{|c|c|c|}
\hline Code & Total & Bar Graph \\
\hline Positive Body Language & 2 & \\
\hline Consistent Focus/Time On Task/Engagement & 5 & \\
\hline Inconsistent Focus/Time Off Task/Not Engaged & 4 & \\
\hline Negative Body Language & 2 & \\
\hline Verbal Participation & 2 & \\
\hline Individual Attention & 0 & \\
\hline Student Interaction with Peers & 12 & \\
\hline Student Non-Interaction With peers & 3 & \\
\hline Fun and Excitement & 1 & \\
\hline Lack of Fun and Excitement & 3 & \\
\hline Meaningfulness of Work & 5 & \\
\hline Not Seeing Meaningfulness of Work & 3 & \\
\hline & & \\
\hline & & \\
\hline & & \\
\hline & & \\
\hline & & \\
\hline & & \\
\hline & & \\
\hline & & \\
\hline
\end{tabular}

Figure 8. Code Frequency Period 2.

Period 3 is a very small class (17 students) and tends to focus a great deal more than other classes. The highest code frequency for this class was Meaningfulness of Work while Student Interaction, Fun and Excitement and Time on Task were still at increased levels (see Figure 9). Outside observers noted the following:

- Engaged with StarLogo program

- Taking risks/changing the code

- Seems to be enjoying this and working with his group members

Particularly of notice in this class was when one of the trained mentor students noticed that I was taking a great deal of extra time and offered, "Mrs. Dowling you keep teaching; I will catch her up." 


\begin{tabular}{l} 
Code \\
\begin{tabular}{|l|l|l|}
\hline Positive Body Language & Total & \\
\hline Consistent Focus/Time On Task/Engagement & 3 & \\
\hline Inconsistent Focus/Time Off Task/Not Engaged & 1 & \\
\hline Negative Body Language & 0 & \\
\hline Verbal Participation & 0 & \\
\hline Individual Attention & 0 & \\
\hline Student Interaction with Peers & 3 & \\
\hline Student Non-Interaction With peers & 0 & \\
\hline Fun and Excitement & 3 & \\
\hline Lack of Fun and Excitement & 0 & \\
\hline Meaningfulness of Work & 6 & \\
\hline Not Seeing Meaningfulness of Work & 1 & \\
\hline & & \\
\hline & & \\
\hline & & \\
\hline & & \\
\hline & & \\
\hline & & \\
\hline
\end{tabular} \\
\hline
\end{tabular}

Figure 9. Code Frequency Period 3

Period 4 is a large class (29 students) and tends to be a talkative class. The frequency code report showed a high degree of student interaction with peers, time on task, and meaningfulness of work (see Figure 10). One observer stated that one of the students was "acting silly, but staying on task and asking questions about the code." Other observers noted another student was "helping group members without prompting" and "seems interested in the activity." 


\begin{tabular}{l} 
Code \\
\begin{tabular}{|l|l|l|}
\hline Positive Body Language & Bar Graph \\
\hline Consistent Focus/Time On Task/Engagement & 0 & \\
\hline Inconsistent Focus/Time Off Task/Not Engaged & 1 & \\
\hline Negative Body Language & 0 & \\
\hline Verbal Participation & 1 & \\
\hline Individual Attention & 1 & \\
\hline Student Interaction with Peers & 9 & \\
\hline Student Non-Interaction With peers & 0 & \\
\hline Fun and Excitement & 3 & \\
\hline Lack of Fun and Excitement & 1 & \\
\hline Meaningfulness of Work & 7 & \\
\hline Not Seeing Meaningfulness of Work & 2 & \\
\hline & & \\
\hline & & \\
\hline & & \\
\hline & & \\
\hline & & \\
\hline & & \\
\hline
\end{tabular} \\
\hline
\end{tabular}

Figure 10. Code Frequency Period 4

Period 5 is a class of average size but is quite social and can be very chaotic. Because of the nature of this class the code frequency chart (see Figure 11) can be deceiving. The frequency of occurrence of the codes for on task vs. off task behavior is quite similar within the data (increased numbers), which is also the case with meaningfulness of work vs. not seeing meaningfulness of work (also increased numbers). On the positive side outside observers noted that some students were "asking lots of questions," "consulting teachers and trained experts" and "working hard to understand learning and the assignment, positive demeanor, works well with others." Contrary to these positive statements, observers also noted:

- Inappropriate talking, communicating often, seeks attention, happy but not necessarily focused

- Off task, needs constant reminders to stay on task

- Head down

- Possibly playing on phone 


\begin{tabular}{|c|c|c|}
\hline Code & Total & Bar Graph \\
\hline Positive Body Language & 6 & \\
\hline Consistent Focus/Time On Task/Engagement & 13 & \\
\hline Inconsistent Focus/Time Off Task/Not Engaged & 11 & \\
\hline Negative Body Language & 1 & \\
\hline Verbal Participation & 4 & \\
\hline Individual Attention & 7 & \\
\hline Student Interaction with Peers & 9 & \\
\hline Student Non-Interaction With peers & 5 & \\
\hline Fun and Excitement & 4 & \\
\hline Lack of Fun and Excitement & 2 & \\
\hline Meaningfulness of Work & 10 & \\
\hline Not Seeing Meaningfulness of Work & 9 & \\
\hline & & \\
\hline & & \\
\hline & & \\
\hline & & \\
\hline & & \\
\hline & & \\
\hline & & \\
\hline
\end{tabular}

Figure 11. Code Frequency Period 5

Period 6 is a unique class in that it also has a high number of low achieving students in addition to two students who are severely autistic. Although it was very quiet, outside observers noted:

- $\quad$ Asked the trained expert for assistance

- $\quad$ Working closely with table partner

- $\quad$ Extremely engaged in activity

- $\quad$ Serves as a leader in the group

- $\quad$ Facilitates the learning of others 


\begin{tabular}{|c|c|c|}
\hline Code & Total & Bar Graph \\
\hline Positive Body Language & 0 & \\
\hline Consistent Focus/Time On Task/Engagement & 5 & \\
\hline Inconsistent Focus/Time Off Task/Not Engaged & 1 & \\
\hline Negative Body Language & 0 & \\
\hline Verbal Participation & 2 & \\
\hline Individual Attention & 0 & \\
\hline Student Interaction with Peers & 8 & \\
\hline Student Non-Interaction With peers & 0 & \\
\hline Fun and Excitement & 2 & \\
\hline Lack of Fun and Excitement & 0 & \\
\hline Meaningfulness of Work & 4 & \\
\hline Not Seeing Meaningfulness of Work & 0 & \\
\hline & & \\
\hline & & \\
\hline & & \\
\hline & & \\
\hline & & \\
\hline & & \\
\hline & & \\
\hline
\end{tabular}

Figure 12. Code Frequency Period 6

In Figure 12, there were no instances of the code individual attention and only two instances of verbal participation. This correlates to the quiet, on task behavior of the group. The code frequency report for this class period also agrees with this observation in that codes dealing with both student interactions with peers and on task behaviors did still occur at a higher frequency in relation to the other codes.

The largest class period and most social of the day is Period 8. Although Period 8 tends to be very talkative and can appear off task, for most activities they do very well and complete activities in a timely manner during the class period. The code frequency report for this period (see Figure 13) is also deceiving. There are no code occurrences for on task behavior and instead the code appears quite often for time off task/inconsistent focus. There is a high frequency of student interaction with peers and the codes for meaningfulness of work and not seeing meaningfulness of work are of equal occurrence. 


\begin{tabular}{l}
\begin{tabular}{|l|l|l|}
\hline Code & Total & Bar Graph \\
\hline Positive Body Language & 0 & \\
\hline Consistent Focus/Time On Task/Engagement & 0 & \\
\hline Inconsistent Focus/Time Off Task/Not Engaged & 4 & \\
\hline Negative Body Language & 1 & \\
\hline Verbal Participation & 0 & \\
\hline Individual Attention & 0 & \\
\hline Student Interaction with Peers & 5 & \\
\hline Student Non-Interaction With peers & 0 & \\
\hline Fun and Excitement & 0 & \\
\hline Lack of Fun and Excitement & 1 & \\
\hline Meaningfulness of Work & 3 & \\
\hline Not Seeing Meaningfulness of Work & 3 & \\
\hline & & \\
\hline & & \\
\hline & & \\
\hline & & \\
\hline & & \\
\hline & & \\
\hline & & \\
\hline
\end{tabular} \\
\hline
\end{tabular}

Figure 13. Code Frequency Period 8

In the case of one student an observer stated that she was "multi-tasking, working on homework and StarLogo" but that she was also "working with table partner." Another student was identified as a "team player." Another student was observed to be "distracting the students around him," "making noises," "making other students laugh," and "tapping mouse on desk (very frustrated with his laptop)." There was a trained mentor in the room available to help other students and an observer noted that the student was "assisting peers" and "clarifying confusion."

Video was also taken during study and analyzed using HyperTranscribe. The outside observer taking the video specifically recorded student-student interactions and because of this video recorded the interactions caught by specifically that observer. This video also caught student-teacher interactions as part of the observation. Each video was analyzed by counting student-student interactions and student-teacher interactions (Table 4). Over the course of 3 days with 2 classes (periods 3 and 4) there was a great deal more student-student (S-S) interactions versus student-teacher (S-T) interactions. Since period 3 is a smaller class (17) there was not as 
noticeable a difference as with Period 4. On one day the S-S interactions for period 4 were 32 versus only 4 S-T interactions. There was a very large number of S-S interactions (86) during a second day that video was taken. The interactions data involving period 4 does correlate to the information in the code frequency chart for period 4 dealing with student interaction with peers and on task/engagement behaviors (Fig. 10).

Table 4 Student-Student Interactions vs. Student-Teacher Interactions

\begin{tabular}{lccc}
\hline Class & Date & $\begin{array}{l}\text { Student-Student } \\
\text { Interactions }\end{array}$ & $\begin{array}{l}\text { Student-Teacher } \\
\text { Interactions }\end{array}$ \\
\hline Period 3 & Feb. 7, 2012 & 70 & 45 \\
\hline Period 4 & Feb. 8, 2012 & 32 & 4 \\
\hline Period 4 & Feb. 9, 2012 & 86 & 43 \\
\hline
\end{tabular}

Another aspect of Research Question 2 that was also analyzed was the content understanding of the mentors themselves. Pre-test and post-test scores were imported into Excel and analyzed (see Figure 14). 


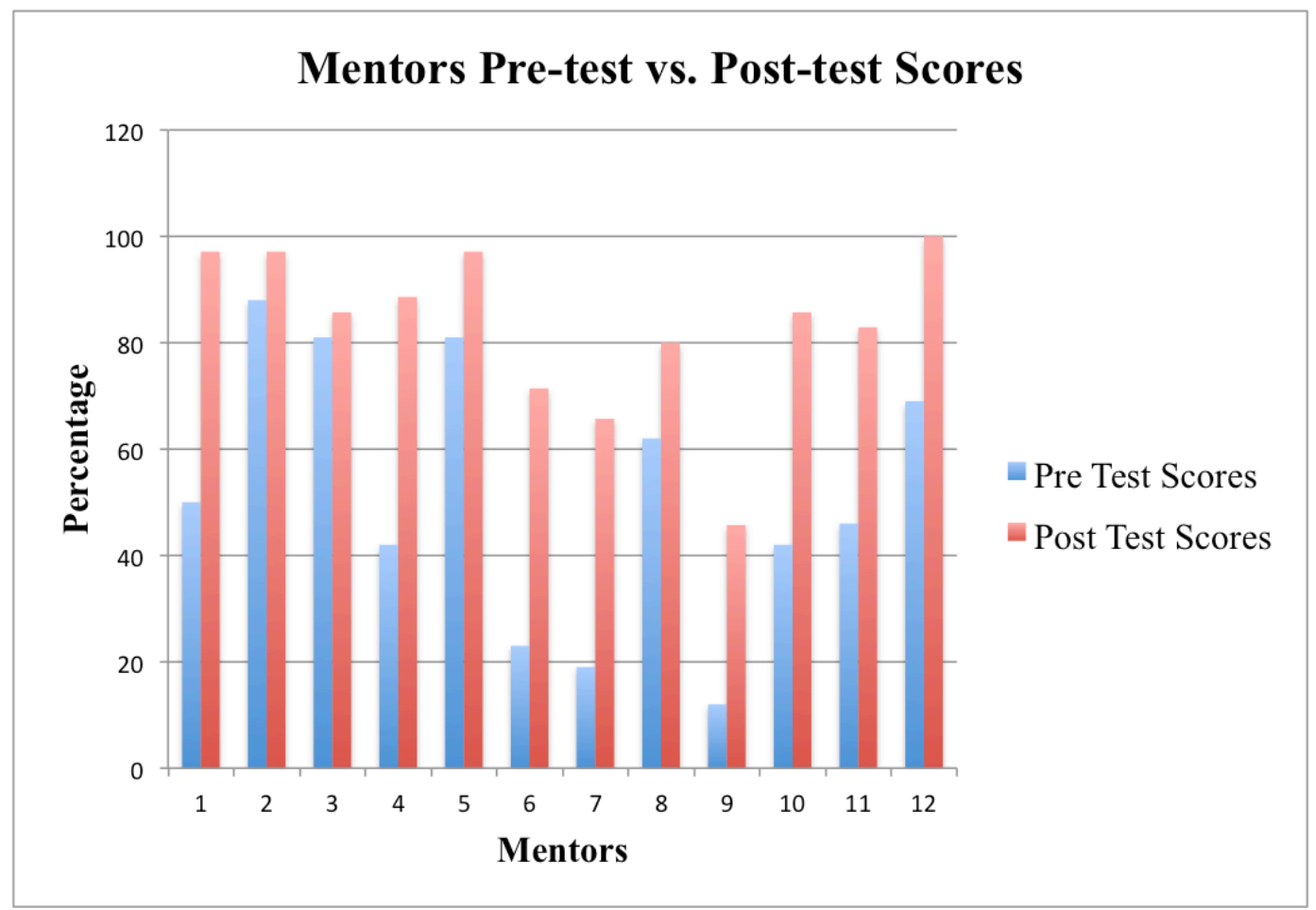

Figure 14. Mentors Pre-test vs. Post-test Score Distribution

All scores for the mentor students increased, with some experiencing a significant jump in scores (students 6 and 7). Scores for the mentor students are detailed in Table 5. 
Table 5 Mentor Students Pre-test vs. Post-test Scores

\begin{tabular}{ccc}
\hline Mentor Students & Pre Test Scores & Post Test Scores \\
1 & 50 & 97 \\
2 & 88 & 97 \\
3 & 81 & 86 \\
4 & 42 & 89 \\
5 & 81 & 97 \\
6 & 23 & 71 \\
7 & 19 & 66 \\
8 & 62 & 80 \\
9 & 12 & 46 \\
10 & 42 & 86 \\
11 & 46 & 100 \\
12 & 69 & \\
\hline & & 83 \\
\hline
\end{tabular}

Student 9 shows typical scores related to his performance throughout the year. This student was identified as having a behavior and learning disability but did possess an affinity for using the StarLogo programming.

A paired-samples t-test was conducted using SPSS to compare all mentors' pre-test scores and post-test scores. There was a significant difference in the mean of differences of the pre-test scores and post-test scores $(\mathrm{M}=31.83, \mathrm{SD}=15.98) ; \mathrm{t}(11)=6.9, \mathrm{p}=.000$. These results indicated that mentors/assistants were able to increase their science content understanding during the project. Students 2, 3 and 5 had scores that did not increase as much since these students had demonstrated mastery of the content prior to the project. 
Table 6 Pre-test versus Post-test Scores Paired-Samples T-test for Mentor Learners

Paired Samples Statistics

\begin{tabular}{llllcc}
\hline & & & & \\
& & Mean & N & Std. Deviation & Std. Error Mean \\
\hline Pair 1 & Post Test Scores & 83.08 & 12 & 15.86 & 4.58 \\
\cline { 2 - 6 } & Pre Test Scores & 51.25 & 12 & 25.46 & 7.35 \\
& & & & \\
& & & & \\
& & & & \\
\end{tabular}

\begin{tabular}{llccc} 
& $\mathrm{N}$ & Correlation & Sig. \\
\hline Pair 1 & $\begin{array}{l}\text { Post Test Scores \& Pre Test } \\
\text { Scores }\end{array}$ & 12 & .798 & .002
\end{tabular}

Paired Samples Test

\begin{tabular}{|c|c|c|c|c|c|c|c|c|c|}
\hline & & \multicolumn{5}{|c|}{ Paired Differences } & \multirow{3}{*}{$\mathrm{t}$} & \multirow{3}{*}{$\mathrm{df}$} & \multirow{3}{*}{$\begin{array}{l}\text { Sig. (2- } \\
\text { tailed) }\end{array}$} \\
\hline & & \multirow{2}{*}{ Mean } & \multirow{2}{*}{$\begin{array}{c}\text { Std. } \\
\text { Deviation }\end{array}$} & \multirow{2}{*}{$\begin{array}{l}\text { Std. } \\
\text { Error } \\
\text { Mean }\end{array}$} & \multicolumn{2}{|c|}{$\begin{array}{c}95 \% \text { Confidence } \\
\text { Interval of the } \\
\text { Difference }\end{array}$} & & & \\
\hline & & & & & Lower & Upper & & & \\
\hline Pair 1 & $\begin{array}{l}\text { Post Test } \\
\text { Scores - } \\
\text { Pre Test } \\
\text { Scores }\end{array}$ & 31.83 & 15.98 & 4.61 & 21.68 & 41.99 & 6.90 & 11 & .000 \\
\hline
\end{tabular}

\section{Summary of Data Analysis}

This chapter presented the results of the study concerning the investigation of the delivery of science content using a game-design metaphor that incorporates student mentors in the classroom. The effect of the design and implementation of the unit on the learning outcomes of the mentors as well as the rest of the learners was also discussed. Data for this study was collected at a mid-Atlantic middle school, and the population consisted of learners 13-14 years of 
age who were enrolled in $8^{\text {th }}$ grade at the school. SPSS was used to perform paired samples t-tests on the pre-test vs. post-test scores of the learners as a whole and also for the mentor students themselves. Student engagement and class engagement checklists as well as field notes were utilized for observations related to on task behaviors, student engagement, and peer interactions. HyperResearch and HyperTranscribe software were also used to examine the same behaviors in addition to analysis of both student-student and student-teacher interactions.

According to the findings, learning outcomes increased across the population with most students increasing their scores significantly. The paired sample t-test showed a significant result (p. <.05) indicating that the intervention was successful with all learners showing improvement from the pre-test to the post-test. This was consistent with the mentor students who also significantly $(\mathrm{p} .<.05)$ increased their performance on the post-test. High levels of on task behaviors, engagement, and peer interaction were observed as well as increased student-student interactions (over student-teacher interactions).

The delivery of content designed using the game-like curricular structure was successful and learning outcomes increased significantly (RQ1). The use of student mentors/assistants contributed to increased student-student/peer interactions and, as indicated in the engagement checklists and video analysis of interactions, the mentors were able to help direct the flow of the class away from difficulties with the StarLogo software towards the necessary learning outcomes (RQ 2). The learning outcomes of the mentor students also increased, at least one of them significantly higher than usual performance levels. 


\section{Chapter V: Discussion}

\section{Overview}

Scientific knowledge is a crucial skill for the 21st Century. Changing the way we view the world is difficult. One way to improve the way students think about science is to change the way they learn about science. One way to achieve this paradigm shift is to engage today's learners with games, models, and simulations. When using these types of instructional methods in delivery of content, the students (and often the teacher) can be lured away from the actual content by a "Siren's Call" as in the Odyssey. When using sophisticated data modeling software, such as StarLogo, it is often difficult for students and teachers alike to ignore the "siren call of the instrument." There is a tendency to shift their focus to the tool instead of on the learning outcome - the science literacy skills. The difficulty, on the one hand, is to maintain lesson focus while on the other dealing with the inherent difficulties this type of software poses for instruction. The aim of this study was to investigate the delivery of science content using a game-design metaphor that incorporated student mentors in the classroom. This study adopted a mixed method to collect and analyze data. The data was collected from a targeted population of learners 13-14 years of age and enrolled in 8th grade at a mid-Atlantic middle school. The study involved approximately 165 students. The learners were able to apply skills from the STEM disciplines (science technology, engineering and math) to solve a real world problem.

\section{Discussion}

This section discusses the findings of the data analysis performed in this study. The research questions were: Research Question 1 examined whether science content can be designed and successfully delivered instructionally using a game-like curricular structure. Research Question 2 examined whether the use of student mentors/assistants could help direct 
and maintain the flow of the class away from the technological issues with the programming software toward the necessary learning outcomes while also increasing the science content understanding acquired by the mentors themselves.

For Research Question 1, the paired samples t-test was significant, hence rejecting the null hypothesis $\left(\mathrm{H}_{0}\right)$. The paired sample t-test showed a significant result $(\mathrm{p} .<.05)$ indicating that the intervention was successful with all learners showing improvement from the pre-test to the post-test. The mentor students also significantly increased their performance on the post-test (p. $<.05)$. Students of low ability who did not do well at all on the pre-test may still have not done well on the post-test but still scored significantly higher than on the pre-test. These results indicate that the delivery of content designed using the game-based metaphor was successful and learning outcomes increased significantly. Students were on task the majority of the time and focused on the content. They also were excited and interested during the project and eager to help one another through the material. In general, students were more likely to interact among themselves than to interact with the teacher. By using the game-based metaphor for design of the instructional delivery, the content had a single organizing structure that demonstrated the objective for the content. This organizing structure was conceptual, procedural and theoretical. The content also had a simple-to-complex organization (Wilson \& Cole, 1992). This mode of delivery also corresponded to what Reigeluth \& Stein (1983) stated related to elaboration theory; instruction is more effective if the learner has control over both content and instructional strategy. Because the students had control over their learning and interaction with the content they took more ownership in their learning.

For Research Question 2, the paired samples t-test for mentor pre-test and post-test scores was significant, hence rejecting the null hypothesis $\left(\mathrm{H}_{0}\right)$ that there is no statistically significant 
difference between the pre-test and post-test scores for the trained mentors during the study. The paired sample t-test showed a significant result $(\mathrm{p} .<.05)$ indicating that the intervention was successful with the mentor students showing improvement from the pre-test to the post-test. This was consistent with the all learners who also significantly $(\mathrm{p} .<.05)$ increased their performance on the post-test. Outside observers used a checklist for class engagement to make observations during different classes. Overall class engagement levels were medium to very high with scores falling predominantly into the high range. Individual Student Engagement Checklists that were utilized by the outside observers also showed a predominance of scores in the medium to very high range with the largest number falling into the high range. From the student checklists it was also observed that there were scores in the low to very low ranges. Individual student observations involved students in individual classes, examining data from different students increased the possibility of a student being observed that typically would not demonstrate on task behavior in class. Outside observers noted in field notes attached to the checklists instances of various types of off task behavior that were typical classroom behaviors for those students (as per my own observations throughout the year). Frequency reports of coded behaviors in the videos demonstrated increased levels of on task behavior, engagement and peer interaction for all classes. The results for each class period were consistent with outside observer field notes and the behavior I am familiar with for those classes also. Videos were also qualitatively analyzed noting student-student versus student-teacher interactions. Studentstudent interactions greatly outnumbered student-teacher interactions in these video portions that also agreed with the field notes of outside observers.

The design of this study possessed a balance between challenge and frustration and induced a flow state in the learners (Csikszentmihalyi, 1990). The end goal was clear and 
learners were able to focus on the end products and deal with the hindrances. The learners became completely involved in the activity because they were presented with a challenge, were able to set goals, had structured control and were provided with clear feedback. The learners were in a "flow state" and became clearly motivated. The game fostered play and produced a state of flow, therefore increasing learning and fostering motivation. The Magic Circle (Huizinga, 1955) was instrumental in the students' learning during this study. Many of today's learners tend to feel the pressure to succeed and become very concerned with whatever grade they might attain on a particular activity. During this study, one of the students was very concerned about whether or not there was would be a test at the culmination of the unit and even requested that he be given a test anyway. During this study learners seemed to be relieved that there was no "grade" for the various levels and to know that they were free to play. The learners were within the Magic Circle while playing within the levels and realized that it was permissible to risk and the possibility of failure was overcome easily. Within the Magic Circle of this particular game ("Cells and Body Systems the Chutes and Ladders Way") they could try again and experiment with the model in the final level as much as they wanted to. It was all right to fail. The learners were able to escape the fear of risk and failure and the opportunities for learning greatly increased.

\section{Conclusions of Study}

All types of games integrate a $21^{\text {st }}$ century skill critical to the design and play of games: systems thinking. Games can also teach higher order thinking skills such as strategic thinking, interpretative analysis, problem solving, plan formulation and execution, and adaptation to rapid change (Klopfer, Osterweil \& Salen, 2009). According to Menn (1993), students will remember $10 \%$ of what they read, $20 \%$ of what they hear, $30 \%$ if they see visuals that are related to what 
they are hearing, $50 \%$ if they watch someone model something while explaining it and almost $90 \%$ if they are able to engage in the job themselves, even if it is only a simulation. There are no magical formulas for a good educational game. The key is in how to frame the problem. In order to successfully implement games in the classroom educators need to find the fun in the learning, not just make a game out of learning. Educators need to devise a way to focus the students such that the learning experience is enhanced by the "fun" (Baker, 2008).

When using games and simulations in the classroom the students as well as the teacher can tend to switch their focus from the learning outcome to the technological aspects of the game or simulation. Using student mentors/assistants in can contribute to increasing the learning outcomes when using games or simulations in delivery of science content. According to Ploetzner, Dillenbourg, Praier, and Traum (1999), when individuals work together in order to understand a particular phenomenon, they often have to justify their explanations to themselves and to each other. By doing this the individuals involved can earn from each other.

Wilson and Cole (1992) describe eight basic strategies for the use of elaboration theory in designing instruction: single organizing structure, simple-to-complex organization, within lesson sequencing, summarizers, synthesizers, analogies, cognitive strategy activators, and learner control. These are generally the strategies used by K-12 educators in design of instruction, however many educators may not be willing to give up control to the learner. Recently this trend is beginning to reverse with the advent of problem-based learning scenarios integrated into instructional delivery. When learner control of instruction is coupled with serious games/simulations in the classroom learning outcomes can be increased.

Motivation is an important part of learning. Csikszentmihalyi (1990) defines flow theory as a method for understanding and implementing motivation. The learner becomes completely 
involved in an activity by being provided with a challenge, setting goals, having structured control and being provided with clear feedback. If the learner is within a "flow state" motivation is a byproduct. Games foster play and produce a state of flow, therefore increasing learning and fostering motivation. According to Lepper and Malone (1987), if an educational game introduces a challenge, creates learner curiosity, provides the learner with a sense of intrinsic control, and uses fantasy to reinforce the instructional goals and to simulate the prior interest in the learner games foster play then it will produce a state of flow, which will increases motivation, and this in turn will support the learning process. This study shows that the use of serious games in the classroom combined with student mentors/assistants can be a successful means of increasing learning outcomes while inspiring motivation and engagement in the middle school learner.

For this study, elaboration theory was successfully used to design an instructional unit that was delivered via a game-like learning environment. The classroom provided an environment that enabled the students to interact with the content in a game-like atmosphere in which they could feel as if they were within the Magic Circle (Huizinga, 1955). The students could experiment within the individual levels and they could imagine what their next moves (products of instruction) would be. As they planned their moves they were afforded the opportunity to fail (when moving one level to the next with exit quizzes) and could experiment with the content. They could attempt the quiz multiple times, if needed, in order to progress to the next level within the rule structure of the game-like learning environment. These behaviors are all distinctive elements of games that can be adapted to the classroom (Klopfer, Osterweil, \& Salen, 2009). Within this learning environment the mentor students were able to interact with other students who needed help in a manner similar to class wide peer tutoring (Greenwood, 
Maheady, \& Delquadri, 2002). These trained mentors as well as the untrained students who volunteered to help others were able to deepen their own understandings of the content by justifying their explanations to themselves and the other students thereby learning from each other. In this way the students were operating within the fifth level of interactivity related to setting (Ploetzner, Dillenbourg, Praier, \& Traum 1999) because they were actively working together and justifying their moves to each other. The 'play' within this game-like learning environment was iterative in that the students had an opportunity to try again if they were not able to move from one level to the next within one attempt at the exit quiz. The 'game' was also recursive because the students could reflect on what they had previously learned up to that point through the activities and apply it to the exit quiz. The 'game' changed in response to their actions. Because the activities met the requirements for a game (being recursive as well as iterative) the unit itself became a 'game' (Klopfer et al., 2009).

This game-like environment also met the seven basic requirements for a learning environment (Houser \& Deloach, 1998):

1. High intensity of interaction and feedback: learners were able to work in cooperative groups and interact with each other in completion of levels. During the activity, outside observers as well as myself noted that the students would help other members of their group to study and review content in order to pass the exit quizzes.

2. Specific goals and established procedures: the game-like environment had a set structure and rules that provided guidelines within which to 'play' the game.

3. Motivation: it was also noted in field notes that students were quite excited when they were able to advance from one level to the next, which in turn provided motivation. 
4. Continual feeling of challenge that was not too frustrating or too boring: students felt challenge in that they thought it necessary to review with each other before taking an exit quiz but they also were not bored. Observers noted on checklists that the students were highly engaged with and interested in the material.

5. Provides direct engagement so that the learner is always on task and interacting with the environment: checklists indicated high to very high levels related to engagement and student-student interaction. Video that was coded for student-student and student-teacher interaction showed almost twice as many student-student interactions as student-teacher.

6. Provides tools and tasks to fit the user and not distract: the activity was designed using a game-like metaphor resembling something the students were familiar with (Chutes and Ladders). The activity did not distract because the students were familiar with the rules of that particular game.

7. Distractions and disruptions are avoided in order not to disrupt the subjective experience: students did not become unnecessarily distracted during the game which in turn lessened the disruptions and enabled them to focus on the activity.

Because these seven requirements for creating a learning environment were met by the 'game' play it was so much fun for the students that the learning in the play was effectively masked.

\section{Significance of the Study}

Given the advent of problem-based learning in the classroom together with the available research on serious and epistemic games, learning outcomes can be improved. When student mentors are involved in the implementation of this type of instructional design, the learning of both the mentor students and the other learners in the classroom can be greatly improved by allowing the learners to become more focused on the content. When able to accomplish this, the 
learners avoid the "Siren's Call" and are actively engaged with the content while gaining control of the educational process; in this way, motivation is increased.

1. In order to advance $21^{\text {st }}$ century skills in today's learner, designing instruction by using a game-based metaphor can aid in advancing learning outcomes. Games teach higher order thinking skills whether the game is computer-based or not. Using a game-based instructional design gives the learner control over the instructional process while engaging them with the content. The result is a higher degree of focus and engagement, which increases motivation. When motivation is increased, learning outcomes also can increase.

2. By using student mentors in the classroom learners can avoid the "Siren's Call" of the instructional method itself and focus on the content. In doing this the learners and the mentors can increase their understanding of the content under study and increased learning outcomes are the result.

\section{Limitations}

The following are some of the limitations that were related to this study:

1. The sample of this study included the $8^{\text {th }}$ grade students enrolled at the school and in my class. All students were given consent forms and all parents/guardians were given assent forms as per Institutional Review Board requirements. Not all student forms were received, however, not all parental assent forms were returned because of this some students' results could not be included in the study. Only observations, field notes, and pre-test/post-test scores of students who had parental assent forms on file could be used. 
2. Instructional design improves over time and repeated implementations. The design for this study was my first attempt at this type of instructional design. Repeated implementations of instruction centered on a game-based metaphor need to be examined in order to strengthen results.

3. Obtaining more observations for all class periods can further strengthen data collection, and therefore analysis. Outside observers being trained more thoroughly will increase consistency in observations. For example outside observers can be trained in the use of the checklists and various aspects of the criteria to be aware of. Also, video can be obtained for more classes and from more varied viewpoints.

\section{Implications}

Results of this research demonstrate the value of using serious games and simulations in the classroom. Games can increase motivation and content engagement. When instructional delivery is centered on a game-based design metaphor an increase in learning outcomes can be observed. The study results provide substantiation as to why there is a need for this type of innovative instructional design. However, educators need to be willing to give more control over the learning process to the learner. If educators can relinquish more control to the learner then motivation, engagement, and learning outcomes can increase. Because the use of game-like design and simulations can aid the acquisition of science content and increase learning outcomes, a new direction can be added to current professional development practices for K-12 educators. Including this type of professional development in the K-12 arena can only add to the repertoire teachers currently have at their disposal for motivating students and increasing learning outcomes. Once teachers understand how to implement this type of game-like design for the classroom (no matter the content area), they can adapt it to their own teaching style and 
classroom environment. The use of student mentors in the classroom can also increase learning outcomes by aiding the learners in directing their attention toward the content under study instead of the "Siren's Call" of the instructional process. When both the learners and the mentors can become more focused on the content an increase in learning outcomes can be observed.

\section{Recommendations for Further Research}

My recommendation for further research is to examine more closely the use of a gamebased design metaphor in the delivery of instructional content. The $21^{\text {st }}$ century learner needs to become more involved in the control of the delivery of content and the instructional process. When the content can be delivered in such a way as to draw the learner into the "game" learning outcomes can increase. Additionally, further studies need to be made in the use of student mentors in the classroom during instruction specifically in middle school instruction. The predominance of the research lies in the use of mentors in the high school in addition to outside of the school environment in relation to such organizations as the Big Brothers/Big Sisters programs. Further research also needs to be conducted into the use of programs such as StarLogo in the classroom in order to examine simulations of real world scenarios in problembased instructional design.

In this study, instructional design in the classroom producing a game-like learning environment did show positive results. More research needs to be geared towards utilizing these types of learning environments. Once more, data has been gathered that can demonstrate an increase in learning outcomes using this type of curricular design professional development for K-12 educators can be geared towards its implementation. Traditionally educators do not react favorably to large amounts of professional development but once it can be shown that these types 
of activities can be successful, they may be more open to new ways of designing their curriculum. This study has demonstrated promise for the embedding of curricular design within a game-like learning environment that can successfully use elaboration theory to enable mastery of science content. This coupled together with student mentors helping each other during this type of activity can also be utilized to increase learning outcomes. Making professional development in designing game-like learning environments available for all teachers could only help add to the already extensive repertoire of best practices available to $21^{\text {st }}$ century educators.

\section{Summary}

This study investigated the delivery of science content using a game-like learning environment that incorporated student mentors in the classroom. According to the findings of this study, learning outcomes can increase when a game-design metaphor is utilized in the instructional design of curriculum. The study also showed that the use of student mentors in the classroom can aid in directing the focus of the learners towards the content being delivered and channel the "Siren's Call" towards the instructional process itself. As part of the mentoring process the learning outcomes of the mentors can also be increased. The literature review for this study supports that serious games and simulations can increase engagement and motivation in the learner by giving them more control over the instructional process and increasing learning. The literature review also supports that the use of student mentors in the classroom during delivery of content can aid in increasing learning for both the learners and the student mentors. 


\section{References}

Ahern, T. (2008a, October). The effectiveness of visual programming for model building in middle school. Paper presented at Frontiers in education conference, 2008. fie 2008. 38th annual. Retrieved from 10.1109/FIE.2008.4720634

Ahern, T. C. (2008b). Computer-mediated communication technology for language acquisition:

A framework for authentic design. In F. Zhang \& B. Barber (Eds.), Handbook on Computer-enhanced Language Learning. (pp. 295-306).

Ahern, T. C. (2009, October). Bridging the gap: Cognitive scaffolding to improve computer programming for middle school teachers. Paper presented at Frontiers in education conference, 2009. fie '09. 39th ieee Retrieved from doi: 10.1109/FIE.2009.5350561

Baker, C. (2008, March). Trying to design a truly entertaining game can defeat even a certified genius. Wired, 16(4). Retrieved from http://www.wired.com/gaming/gamingreviews/magazine/16-04/pl_games

Bateson, G. (1972). Steps to an ecology of mind. NY: Ballantine.

Beesley, A., Clark, T., Barker, J., Germeroth, C., Apthorp, H., \& Mid-continent Research for Education and Learning (McREL). (2010). Expeditionary Learning Schools: Theory of Action and Literature Review of Motivation, Character, and Engagement. Mid-continent Research for Education and Learning (McREL).

Catrambone, R. (1998). The subgoal learning model: creating better examples so that students can solve novel problems. Journal of Experimental Psychology, 127(4), 355-376.

Converse, N., \& Lignugaris/Kraft, B. (2009). Evaluation of a school-based mentoring program for at-risk middle school youth. Remedial and Special Education, 30(1), 33-46. 
Csikszentmihalyi, M. (1990). Flow: The psychology of optimal experience. New York: Harper \& Row.

Dotterer, A. M., \& Lowe, K. (2011). Classroom Context, School Engagement, and Academic Achievement in Early Adolescence. Journal Of Youth And Adolescence, 40(12), 16491660.

Federation of American Scientists. (2006). Harnessing the Power of Video Games for Learning. http://www.fas.org/gamesummit/Resources/Summit\%20on\%20Educational\%20Games.p $\underline{\mathrm{df}}$

Fulk, B. M., \& King, K. (2001). Classwide peer tutoring at work. Teaching Exceptional Children, 34(2), 49. Retrieved from EBSCO host.

Gee, J. P. (2003). What video games have to teach us about learning and literacy. NY: Palgrave Macmillan.

Greenwood, C. R., Maheady, L., \& Delquadri, J. C. (2002). Class-wide peer tutoring. In G. Stoner, M. R. Shinn, \& H. Walker (Eds.), Interventions for achievement and behavior problems, (2nd ed., pp. 611-649). Washington, DC: National Association of School Psychologists.

Grigg, W. S., Lauko, M. A., \& Brockway, D. M. (2005). The Nation's Report Card Science 2005, (NCES 2006-466). Washington, DC: U.S Government Printing Office

Grubbs, N., \& Boes, S.R. (2009). The effects of the peer tutoring program: An action research study of the effectiveness of the peer tutoring program at one suburban middle school. Georgia School Counselor Association Journal, 16(1), 21-3.

Heibert, J., \& Stigler, J. W. (2004). A world of difference: Classrooms abroad provide lessons in teaching math and science. Journal of Staff Development, 24(4), 10 -15. 
Herrera, C., Kauh, T., Cooney, S., Grossman, J., \& McMaken, J. (2008). High school students as mentors: Findings from the big brothers big sisters school-based mentoring impact study. Public/Private Ventures, Retrieved from http://www.ppv.org/ppv/publication.asp? search_id=0\&publication_id=252§ion_id=12

Hoonhout, J., Diederiks, E. \& Stienstra, M. “Designing fun, and test it too," Usability Professionals’ Association, Marriott City Center Minneapolis, Minnesota. Available at: http://www.upassoc.org/conferences_and_events/upa_conference/2004/program/Worksh ops/DesigningFun.html

Houser, R., \& Deloach, S. (1998). "Learning from games: Seven principles of effective design," Technical Communication (August, 1998), pp. 319-329.

Huizinga, J. (1955). Homo ludens: A study of the play element in culture. Boston: Beacon Press. Jones, R. D. (2009). Student engagement teacher handbook. Rexford, New York: International Center for Leadership in Education. Retrieved from http://www.leadered.com/pdf/Student Engage handbook excerpt.pdf

Kamps, D. M., Greenwood, C., Arreaga-Mayer, C., Veerkamp, M. B., Utley, C., Tapia, Y., Bowman-Perrott, L., Bannister, H. (2008). The efficacy of classwide peer tutoring in middle schools. Education and Treatment of Children, 31(2), 119-152. Retrieved August 4, 2011, from Project MUSE database.

Kaptelin, V., \& Cole, M. (2002). Individual and collective activities in educational computer game playing. In T. Kosmann, R. Hall, \& N. Miyake (Eds.), g2057CSCL 2: Carrying forward the conversation (pp. 303-316). Mahwah, NJ: Lawrence Erlbaum.

Ke, F. (2008). A case study of computer gaming for math: Engaged learning from gameplay? Computers \& Education, 51, 1609-1620. 
King, A., Staffieri, A., \& Adelgais, A. (1998). Mutual peer tutoring: Effects of structuring tutorial interaction to scaffold peer learning. Journal of Educational Psychology, 90(1), 134-152. doi:10.1037/0022-0663.90.1.134

Klopfer, E. (2003). Technologies to support the creation of complex systems models - using starlogo software with students. BioSystems, 71, 111-122.

Klopfer, E., \& Begel, A. (2003) "StarLogo under the hood and in the classroom," Kybernetes, Vol. 32 Iss: $1 / 2$, pp. $15-37$

Klopfer, E., Colella, V., \& Resnick, M. (2002). New paths on a StarLogo adventure. Computers \& Graphics, 26, 615-622.

Klopfer, E., Osterwell, S., Groff, J., \& Hass, J. (2009). Using the technology of today, in the classroom today. Boston: The Education Arcade.

Klopfer, E., Osterweil, S., \& Salen, K. (2009). Moving learning games forward. Retrieved from http://education.mit.edu/papers/MovingLearningGamesForward_EdArcade.pdf

Lepper, M. R., \& Malone, T. W. (1987). "Intrinsic motivation and instructional effectiveness in computer-based education,” In R. E. Snow \& M. J. Farr (Eds.) Aptitude, learning, and instruction: Vol. 3. Cognitive and affective process analysis, (1987) Hillsdale NJ: Erlbaum, pp. 255-286.

Maheady, L, \& Gard, J. (2010). Classwide peer tutoring: practice, theory, research, and personal narrative. Intervention in School and Clinic, 46(2), Retrieved from http://isc.sagepub.com.www.libproxy.wvu.edu/content/46/2/71.full.pdf + html doi: $10.1177 / 1053451210376359$ 
Massachusetts Institute of Technology (2010). StarLogo TNG (Version 1.5) [Computer software]. Cambridge, Massachussets: Massachusetts Institute of Technology. Retrieved March 28, 2012. Available from http://education.mit.edu/projects/starlogo-tng

Mayer, R. E., \& Johnson, C. I. (2010). Adding instructional features that promote learning in a game-like environment. Journal of Educational Computing Research, 42(3), 241-265.

Menn, D. (1993, October). Multimedia in education. PC World, M52-M60

Paras, B., \& Bizzocchi, J. (2005, June). Game, motivation, and effective learning: An integrated model for educational game design. Proceedings of Digital games research association conference, Vancouver, British Columbia, Canada. Retrieved from http://www.digra.org/d1/db/06276.18065.pdf

Ploetzner R., Dillenbourg P., Praier M. \& Traum D. (1999) Learning by explaining to oneself and to others. In P. Dillenbourg (Ed) Collaborative-learning: Cognitive and Computational Approaches, (pp. 103-121). Oxford: Elsevier

Prensky, M. (2001). Digital game-based learning. NY: McGraw-Hill Companies. Prensky, M. (2002). The motivation of gameplay or, the real 21 st century learning revolution. On the Horizon, 10(1).

Reigeluth, C., \& Darwazeh, A. (1982). The elaboration theory’s procedure for designing instruction. Journal of Instructional Development, 5(5), 22-32.

Reigeluth, C., Merrill, M., Wilson, B., \& Spiller, R. (1980). The elaboration theory of instruction: A model for sequencing and synthesizing instruction. Instructional Science, 9(3), 195-219.

Reigeluth, C. M., \& Stein, R. (1983). Elaboration theory. In C. M. Reigeluth (Ed.), Instructionaldesign theories and models: An overview of their current status. Hillsdale NJ: Erlbaum. 
ResearchWare, Inc. (2011). HyperRESEARCH (Version 3.0.2) [Computer Software]. Available from http://www.researchware.com

ResearchWare, Inc. (2011). HyperTRANSCRIBE (Version 1.5.3) [Computer Software]. Available from http://www.researchware.com

Salen, K. \& Zimmerman, E. (2004). Rules of play: Game design fundamentals. Massachusetts Institute of Technology.

Schwartz, D., Chase, C., Oppezzo, M., \& Chin, D. (2011). Practicing versus inventing with contrasting cases: The effects of telling first on learning and transfer. Journal of Educational Psychology, 103(4), 759-775.

Shaffer, D. 2005. Epistemic games. Innovate: Journal of online education, 1 (6). Retrieved from http://www.innovateonline.info/index.php?view=article\&id=79

Squire, K. (2005). Changing the game: what happens when video games enter the classroom? Innovate: Journal of online education, 1(6). Retrieved from http://www.innovateonline.info/index.php?view=article\&id=82

U.S. Department of Education, Institute of Education Sciences, National Center for Education Statistics, National Assessment of Educational Progress (NAEP), 2009 Science Assessment.

U.S. Department of Education, Office of Planning, Evaluation and Policy Development, Policy and Program Studies Service, State and Local Implementation of the No Child Left Behind Act, Volume II-Teacher Quality Under NCLB: Interim Report, Washington, D.C., 2007. 
Vogel, J. J., Vogel, D., Cannon-Bowers, J., Bowers, C., Muse, K., \& Wright, M. (2006). Computer gaming and interactive simulations for learning: A meta-analysis. Journal of Educational Computing Research, 34(3), 229-243.

West Virginia Department of Education. Eighth Grade Science Objectives . [available at]. http://wveis.k12.wv.us/Teach21/public/cso/popUp.cfm Retrieved March 27, 2012.

Wilson, B., \& Cole, P. (1992). A critical review of elaboration theory. Educational Technology Research and Development, 40 (3), 63-79. 


\section{Appendices}

Appendix A: West Virginia Eighth Grade Science Content Standards and Objectives for Basic Biology (with the exception of heredity and genetics)

\begin{tabular}{|c|l|}
\hline SC.O.8.2.02 & $\begin{array}{l}\text { examine and describe the structures and functions of cell } \\
\text { organelles. }\end{array}$ \\
\hline SC.O.8.2.03 & $\begin{array}{l}\text { explain how the circulatory, respiratory and reproductive } \\
\text { systems work together in the human body. }\end{array}$ \\
\hline SC.O.8.2.04 & $\begin{array}{l}\text { compare the variations in cells, tissues and organs of the } \\
\text { circulatory, respiratory and reproductive systems of different } \\
\text { organisms. }\end{array}$ \\
\hline SC.O.8.2.05 & $\begin{array}{l}\text { discuss how living cells obtain the essentials of life through } \\
\text { chemical reactions of fermentation, respiration and } \\
\text { photosynthesis. }\end{array}$ \\
\hline
\end{tabular}


Appendix B: Rules of the Game

Cells and Body Systems the Chutes and Ladders Way!

The Object of the Game: Be the first group to have all members reach and complete Level 4....The Epidemic Game!

1. Each Level of the game board corresponds to the Cells and Body Systems Unit Levels:

a. Level 1: Cells and Levels of Organization

b. Level 2: Body Systems

c. Level 3: Group Presentation of Cells and Body Systems

d. Level 4: StarLogo Epidemic Game

2. Each level must be completed according to the individual rules for each level. There will be a general timeline for completion of levels.

3. Each group must divide responsibilities between individual group members and cannot advance to the next level until each member has successfully completed a given task (this must be confirmed by the teacher). Each group member must also complete the Level Exit Ticket for that level before they advance.

4. Once each individual group member has reached the chute/ladder for a given level their individual tokens can move to the next level and the group token can advance to the next level. This can only happen if the group AND the members have successfully completed all tasks.

\section{IMPORTANT TO REMEMBER: ALL MEMBERS MUST PARTICPATE IN ORDER FOR THE GROUP TO ADVANCE!!!!!!!!}

6. This process is to be followed for each level until all groups have arrived at the final level. 


\section{Appendix C: Game Level Descriptions}

Level 1 - Cells and Levels of Organization

\begin{tabular}{|c|c|c|c|}
\hline Content Covered & Activity Choices & $\begin{array}{c}\text { Date } \\
\text { Completed? }\end{array}$ & $\begin{array}{l}\text { Who } \\
\text { Completed } \\
\text { What? }\end{array}$ \\
\hline $\begin{array}{c}\text { Plant Cell - Basic } \\
\text { Structure and } \\
\text { Organelles (functions) }\end{array}$ & $\begin{array}{c}\text { Definitions/Descriptions } \\
\text { Key Word = "Remembering" } \\
\text { (glossary, flash cards, concept map, } \\
\text { powerpoint, diagram, writing, outline, } \\
\text { etc.) }\end{array}$ & & \\
\hline $\begin{array}{c}\text { Animal Cell - Basic } \\
\text { Structure and } \\
\text { Organelles (functions) }\end{array}$ & $\begin{array}{c}\text { Definitions/Descriptions } \\
\text { Key Word = "Remembering" } \\
\text { (glossary, flash cards, concept map, } \\
\text { powerpoint, diagram, writing, outline, } \\
\text { etc.) }\end{array}$ & & \\
\hline $\begin{array}{l}\text { Plant Cell vs Animal } \\
\text { Cell }\end{array}$ & $\begin{array}{l}\text { Compare/Contrast Structure and } \\
\text { Function (organelles involved, } \\
\text { photosynthesis, respiration and } \\
\text { fermentation) } \\
\text { Key Word = "Understanding" } \\
\text { (Venn diagram, comparison table, } \\
\text { cartoons, collage, poster, Glogster, } \\
\text { Prezi, etc. }\end{array}$ & & \\
\hline
\end{tabular}

Group Rules:

1. You must take part in and complete each group activity.

2. You must play your role in the group (there is no "leader," this is a GROUP effort).

3. You have the right to ask anyone else in your group for help.

4. You have the duty to assist anyone who asks for help.

5. You must help other group members without doing their work for them.

6. Be a good listener.

7. Everybody helps. 
Level 2 - Body Systems

\begin{tabular}{|c|c|c|c|}
\hline Content Covered & Activity Choices & $\begin{array}{c}\text { Date } \\
\text { Completed? }\end{array}$ & $\begin{array}{c}\text { Who } \\
\text { Completed } \\
\text { What? }\end{array}$ \\
\hline $\begin{array}{c}\text { Body Systems - Structure } \\
\text { and Function of each } \\
\text { (Skeletal/Muscular, } \\
\text { Circulatory, Respiratory, } \\
\text { Immune, Digestive/Excretory) }\end{array}$ & $\begin{array}{c}\text { Definitions/Descriptions } \\
\text { Key Word = "Remembering" } \\
\text { (glossary, flash cards, } \\
\text { concept map, powerpoint, } \\
\text { diagrams, writing, outline, etc.) }\end{array}$ & & \\
\hline $\begin{array}{c}\text { Body Systems - How do } \\
\text { they interact with each other? } \\
\text { (Skeletal/Muscular, } \\
\text { Circulatory, Respiratory, } \\
\text { Immune, Digestive/Excretory) }\end{array}$ & $\begin{array}{c}\text { Compare/Contrast Structure } \\
\text { and Function } \\
\text { Key Word }= \\
\text { "Understanding" } \\
\text { (Venn diagram, comparison } \\
\text { table, cartoons, collage, poster, } \\
\text { Glogster, Prezi, etc. }\end{array}$ & & \\
\hline
\end{tabular}

Group Rules:

1. You must take part in and complete each group activity.

2. You must play your role in the group (there is no "leader," this is a GROUP effort).

3. You have the right to ask anyone else in your group for help.

4. You have the duty to assist anyone who asks for help.

5. You must help other group members without doing their work for them.

6. Be a good listener.

7. Everybody helps. 
Level 3 - Group Presentations of Cells and Body Systems

\begin{tabular}{|c|c|c|c|}
\hline Content Covered & Activity Choices & $\begin{array}{c}\text { Date } \\
\text { Completed? }\end{array}$ & $\begin{array}{c}\text { Who } \\
\text { Completed } \\
\text { What? }\end{array}$ \\
\hline $\begin{array}{l}\text { Plant Cell vs. Animal } \\
\text { Cell }\end{array}$ & $\begin{array}{c}\text { Compare/Contrast Structure and } \\
\text { Function (organelles involved, } \\
\text { photosynthesis, respiration and } \\
\text { fermentation) } \\
\text { Key Words = "Application } \\
\text { Synthesis and Analysis" } \\
\text { (Diagrams, Models, Report, } \\
\text { Story, Play, Song, Book, Poetry, } \\
\text { Game, etc.) }\end{array}$ & & \\
\hline $\begin{array}{c}\text { Body Systems - } \\
\text { How do they interact } \\
\text { with each other? } \\
\\
\text { (Skeletal/Muscular, } \\
\text { Circulatory, } \\
\text { Respiratory, Immune, } \\
\text { Digestive/Excretory) }\end{array}$ & $\begin{array}{c}\text { Compare/Contrast Structure } \\
\text { and Function } \\
\text { Key Words = "Application } \\
\text { Synthesis and Analysis" } \\
\text { (Diagrams, Models, Report, } \\
\text { Story, Play, Song, Book, Poetry, } \\
\text { Game, etc.) }\end{array}$ & & \\
\hline
\end{tabular}

Group Rules:

1. You must take part in and complete each group activity.

2. You must play your role in the group (there is no "leader," this is a GROUP effort).

3. You have the right to ask anyone else in your group for help.

4. You have the duty to assist anyone who asks for help.

5. You must help other group members without doing their work for them.

6. Be a good listener.

7. Everybody helps. 
Level 4 - StarLogo Epidemic Game

\begin{tabular}{|c|c|}
\hline Content Covered & Activity Choices \\
\hline Epidemiology & $\begin{array}{c}\text { Discussion -What is an epidemic } \\
\text { and how does it function? }\end{array}$ \\
\hline StarLogo Game Programming & \\
\hline & Program StarLogo Epidemic Game \\
using online tutorial \\
\end{tabular}

This portion of the project is an individual activity. There will be experts available to help you with the programming!!!!!!

Successfully progress through all levels of the game.....

YOU WIN!!!!!!!!!!!!!!!!!!!!! 
Appendix D: Blooms Digital Taxonomy
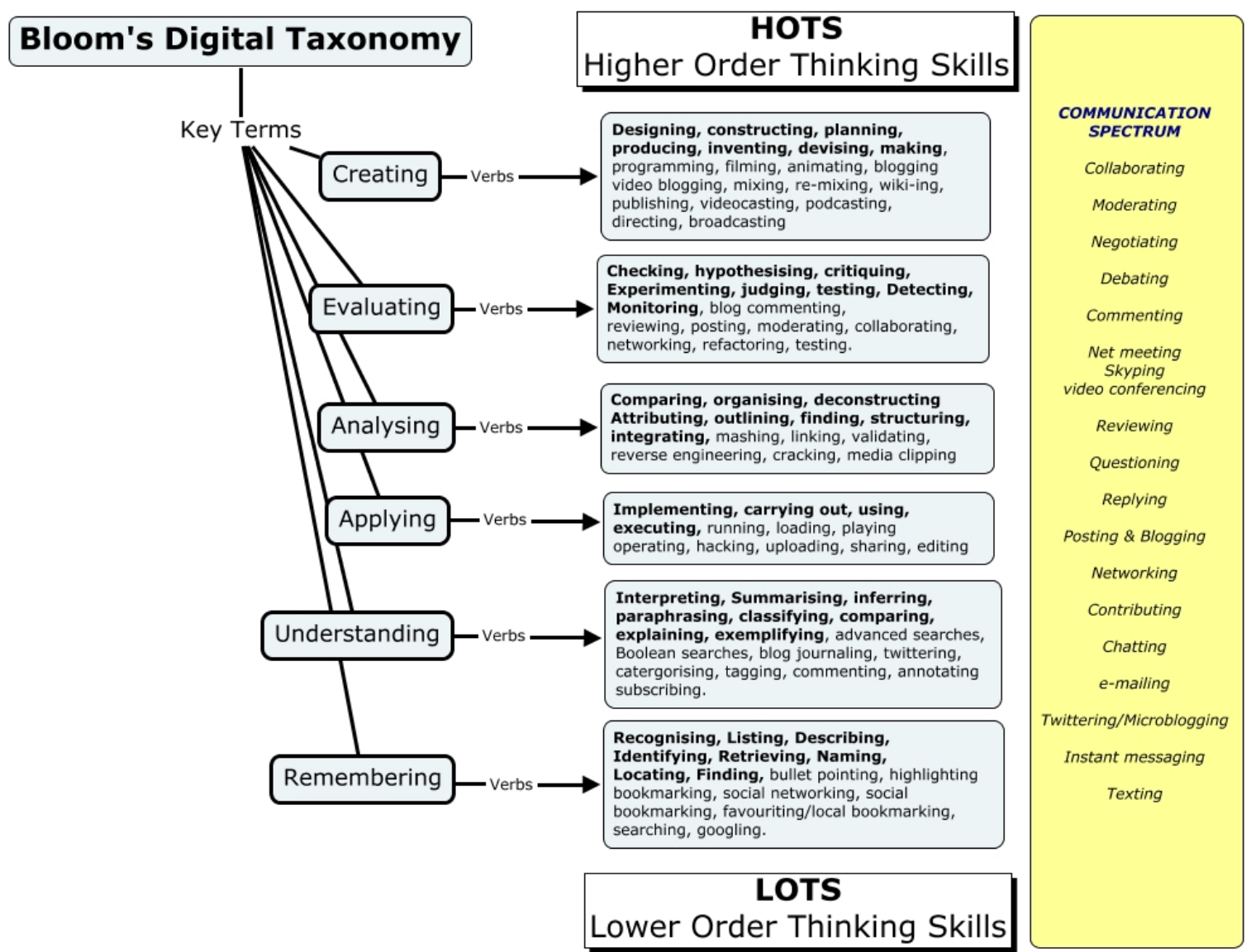

\section{LOTS}


Appendix E: Level 1 Exit Ticket

Level 1 Exit Ticket

1. Animal cells have a chloroplast.
a) True
b) False

2. Both animal and plant cells have a cell wall.
a) True
b) False

3. Lysosomes are only found in animal cells.
a) True
b) False

4. Both animal cells and plant cells contain ribosomes.
a) True
b) False

5. Animal cells have one large vacuole that stores food, water, and other materials.
a) True
b) False

6. Protects the nucleus, materials pass in \& out through pores
a) Nuclear membrane
b) Cell membrane
c) Cytoplasm
d) Ribosomes 
7. Rod-shaped organelles that produce energy
a) Cytoplasm
b) Ribosomes
c) Mitochondria
d) Golgi Body

8. Structures that function as factories that produce proteins
a) Nucleolus
b) Ribosomes
c) Golgi Body
d) Endoplasmic reticulum

9. Directs all of the cell's activities, including reproduction
a) Ribosomes
b) Mitochondria
c) Nucleus
d) Lysosome

10. Gel-like fluid in which many organelles are found
a) Nucleolus
b) Mitochondria
c) Endoplasmic reticulum
d) Cytoplasm

11. Levels of organization
a) cells, tissues, systems, organs
b) cells, tissues, organs, systems
c) tissues, organs, cells, systems
d) systems, cells, organs, tissues 
12. Network of passageways that carry the materials from one part of the cell to another
a) Mitochondria
b) Golgi Body
c) Lysosome
d) Endoplasmic reticulum

13. Receives materials through the endoplasmic reticulum and sends them to other parts of the cell
a) Golgi Body
b) Vacuoles
c) Ribosomes
d) Cytoplasm

14. The structure where ribosomes are made
a) Golgi Body
b) Endoplasmic reticulum
c) Nucleus
d) Vacuoles

15. In animal cells, they contain chemicals that break down food particles and worn out-cell parts
a) Ribosomes
b) Vacuoles
c) Lysosomes
d) Golgi Body 
16. Which process occurs only in plants?
a) Fermentation
b) Respiration
c) Krebbs Cycle
d) Photosynthesis

17. Which process occurs only in animals?
a) Fermentation
b) Respiration
c) Night Reactions
d) Photosynthesis

18. Which process occurs without oxygen and in bacteria?
a) Fermentation
b) Respiration
c) Krebbs Cycle
d) Photosynthesis

19. Which two processes are most closely related?
a) Fermentation and photosynthesis
b) Respiration and fermentation
c) Respiration and Night Reactions
d) Photosynthesis and respiration

20. Which process requires carbon dioxide in order to make food?
a) Photosynthesis
b) Respiration
c) Krebbs Cycle
d) Fermentation 


\section{Appendix F: Level 2 Exit Ticket}

Level 2 Exit Ticket

1. The main organs of the respiratory system are the
a. kidneys
b. lungs
c. intestines
d. liver

2. __ is the process by which the body maintains a stable internal environment.
a. homeostasis
b. absorption
c. respiration
d. acidosis

3. The digestive system and the system work together to breakdown food and transport it to cells.
a. excretory
b. integumentary
c. reproductive
d. circulatory

4. Food molecules pass from the small intestine into the bloodstreamthrough tiny fingerlike projections called
a. nephrons
b. alveoli
c. cristae
d. villi 
5. The waste liquid produced by the kidneys is called
a. sweat
b. urine
c. bile
d. tears

6. The circulatory system and the system work together to remove carbon dioxide from the body.
a. digestive
b. urinary
c. respiratory
d. excretory

7.What 'disease-fighting' system is the lymphatic system a part of?
a. respiratory
b. immune
c. digestive
d. excretory

8. Thin-walled sacs in the lungs are called
a. villi
b. alveoli
c. enzymes
d. lipids 
9. Which body system in humans transports materials needed for survival?
a. circulatory system
b. digestive system
c. excretory system
d. respiratory system

10. How many bones are in the normal human body?
a. 210
b. 2
c. 206
d. 640

11. Kidneys help the body by
a. filtering wastes from blood.
b. removing extra body heat.
c. removing carbon dioxide.
d. absorbing waste through the walls of villi.

12. How does the digestive system work?
a. carries oxygen and glucose to the cells.
b. allows blood that passes through the lungs to drop off $\mathrm{CO} 2$ and pick up $\mathrm{O} 2$
c. eliminates waste products from the body
d. breaks down food into nutrients (including glucose)

13. How does the respiratory system work?
a. carries oxygen and glucose to the cells.
b. allows blood that passes through the lungs to drop off $\mathrm{CO} 2$ and pick up $\mathrm{O} 2$
c. eliminates waste products from the body
d. breaks down food into nutrients (including glucose) 
14. How does the circulatory system work?
a. carries oxygen and glucose to the cells.
b. allows blood that passes through the lungs to drop off $\mathrm{CO} 2$ and pick up $\mathrm{O} 2$
c. eliminates waste products from the body
d. breaks down food into nutrients (including glucose)

15. How does the excretory system work?
a. carries oxygen and glucose to the cells.
b. allows blood that passes through the lungs to drop off $\mathrm{CO} 2$ and pick up $\mathrm{O} 2$
c. eliminates waste products from the body
d. breaks down food into nutrients (including glucose)

16. Combine efforts to break down food and transport it to cells
a. digestive and circulatory systems
b. digestive and excretory systems
c. respiratory and circulatory systems
d. respiratory and muscular systems

17. Combine efforts to support and protect the internal organs
a. digestive and circulatory systems
b. muscular and skeletal systems
c. respiratory and circulatory systems
d. integumentary and skeletal systems

18. Which organ is not in the respiratory system?
a. nose
b. bronchi
c. pancreas
d. trachea 
19. What is the name of the muscle that you use when breathing properly?
a. diaphragm
b. alveoli
c. bronchi
d. gluteus maximus

20. Which organ produces bile?
a. stomach
b. pancreas
c. gall bladder
d. liver

21. What tube is part of the digestive system that is between the mouth and the stomach?
a. trachea
b. esophagus
c. ureters
d. nephrons

22. One of the main functions of the nervous system is to receive stimuli from inside and outside the body.
a. true
b. false

23. What is the main job of the excretory system?
a. to break down foods into nutrients that can be used by the body.
b. take in oxygen and exhale waste like carbon dioxide.
c. to filter toxins and excess water out of cells.
d. take in oxygen and exhale waste like carbon dioxide. 
24. How many chambers are there in the human heart?
a. one
b. two
c. three
d. four

25. Blood travels through which of the following organs?
a. kidneys
b. liver
c. lungs
d. all of the above 
Appendix G: Level 3 Presentation Rubric

ented less

material than the others.
All students shared

equally in the

presentation 
Appendix H: Pre-Test

Name:

Class Period:

Date:

Cells, Systems, Processes and Plant Anatomy Post - Test

\section{MULTIPLE CHOICE}

1.Which body system in humans transports materials needed for survival?
a. circulatory system
c. excretory system
b. digestive system
d. respiratory system

2.Every cell contains
a. the same cell structures
c. the same DNA sequences
b. genes from two parents
d. common features as well as differences that determine the cell's structure and function

3. Which are produced during photosynthesis?
a. carbon dioxide and minerals
c. oxygen and sugar
b. carbon dioxide and sugar
d. oxygen and minerals

4. Which statement about cells is NOT true?
a. cells are the basic unit of structure and c. cells contain many chemicals function in living things
b. cells are produced from nonliving d. cells make up all living things materials

5.The reproductive organs of a rose bush are found in
a. the stem
c. the thorns
b. the flower
d. the leaves

6.Which of the following is responsible for pollination in seed plants?
a. insects
c. birds and other animals
b. wind
d. all of the above

7.Sperm cells produced by the plant are found in
a. the pollen
c. the ovary
b. a bud
d. the ripened fruit 
8.Similar cells that are grouped together and perform a similar function are called
a. an organ
c. a species
b. a tissue
d. an organism

9.The products of cellular respiration become the raw materials of which process?
a. protein synthesis
c. photosynthesis
b. DNA replication
d. all of the above

10. Which cellular process requires the presence of oxygen?
a. photosynthesis
c. aerobic respiration
b. anaerobic respiration
d. all of the above

\section{MATCHING}
a. endoplasmic reticulum
g. cytoplasm
b. nucleus
h. Golgi body
c. ribosomes
i. vacuole
d. mitochondrion
j. cell wall
e. chloroplasts
k. lysosome
f. cell membrane

1.these organelles capture energy from sunlight and use it to produce food for the cell

2.directs the cell's activities, including reproduction

3.most of the cell's energy is produced within these rod-shaped organelles

4. store food, water, wastes and other materials; plant cells have only one large one

5.produce proteins

6.network of passages that carries materials from one part of the cell to another

7.receives materials from the endoplasmic reticulum and sends to other parts of the cell

8.a stiff wall that surrounds the cell membrane and gives a cell it's shape; only found in plant cells

9.the area between the cell membrane and the nucleus; contains a gel-like fluid in which the cell organelles are found

10.protects the cell and regulates what substances enter and leave the cell 
11.found in animal cells; contain chemicals that break down food particles and worn-out cell parts

\section{SHORT ANSWER}

1. What is the equation for photosynthesis?

2. How do the processes of photosynthesis and cellular respiration complement each other? (Hint: Describe what both processes are and how they are related to each other)

3. Describe the levels of organization in plants and animals. (Hint: Describe each part of the system and place in order from simplest to most complex).

4. What role do the respiratory, digestive, and circulatory systems play in providing cells in the body with energy? (Hint: Describe how each system works and what relates it to the other systems listed).

5. What is fermentation? 


\section{Appendix I: Post-Test}

Cells and Body Systems Post-Test

1. Animal cells do not have a chloroplast.

a) True

b) False

2. Both animal and plant cells have a cell wall.

a) True

b) False

3. Plant cells have one large vacuole that stores food, water, and other materials.

a) True

b) False

4. Rod-shaped organelles that produce energy

a) Cytoplasm

b) Ribosomes

c) Mitochondria

d) Golgi Body

5. Structures that function as factories that produce proteins
a) Nucleolus
b) Ribosomes
c) Golgi Body
d) Endoplasmic reticulum 
6. Directs all of the cell's activities, including reproduction
a) Ribosomes
b) Mitochondria
c) Lysosome
d) Nucleus

7. Gel-like fluid in which many organelles are found
a) Nucleolus
b) Mitochondria
c) Endoplasmic reticulum
d) Cytoplasm

\section{Levels of organization}

a) cells, tissues, systems, organs

b) cells, tissues, organs, systems

c) tissues, organs, cells, systems

d) systems, cells, organs, tissues

9. Network of passageways that carry the materials from one part of the cell to another
a) Mitochondria
b) Golgi Body
c) Lysosome
d) Endoplasmic reticulum 
10. Receives materials through the endoplasmic reticulum and sends them to other parts of the cell
a) Golgi Body
b) Vacuoles
c) Ribosomes
d) Cytoplasm

11. The structure where ribosomes are made
a) Golgi Body
b) Endoplasmic reticulum
c) Nucleus
d) Vacuoles

12. Which process occurs only in plants?
a) Fermentation
b) Respiration
c) Krebbs Cycle
d) Photosynthesis

13. Which process occurs only in animals?
a) Fermentation
b) Respiration
c) Night Reactions
d) Photosynthesis 
14. Which process occurs without oxygen and in bacteria?
a) Fermentation
b) Respiration
c) Krebbs Cycle
d) Photosynthesis

15. Which two processes are most closely related?
a) Fermentation and photosynthesis
b) Respiration and fermentation
c) Respiration and Night Reactions
d) Photosynthesis and respiration

16. Which process requires carbon dioxide in order to make food?
a) Photosynthesis
b) Respiration
c) Krebbs Cycle
d) Fermentation

17. The main organs of the respiratory system are the
a. lungs
b. kidneys
c. intestines
d. liver 
18. The digestive system and the system work together to break down food and transport it to cells.
a. excretory
b. integumentary
c. reproductive
d. circulatory

19. Food molecules pass from the small intestine into the bloodstream through tiny fingerlike projections called
a. nephrons
b. alveoli
c. villi
d. cristae

20. The waste liquid produced by the kidneys is called
a. sweat
b. urine
c. bile
d. tears 
21. The circulatory system and the system work together to remove carbon dioxide from the body.
a. digestive
b. urinary
c. respiratory
d. excretory

22. What ëdisease-fightingí system is the lymphatic system a part of?
a. respiratory
b. excretory
c. digestive
d. immune

23. Thin-walled sacs in the lungs are called
a. villi
b. alveoli
c. enzynes
d. lipids

24. Which body system in humans transports materials needed for survival?
a. circulatory system
b. digestive system
c. excretory system
d. respiratory system 
25. Kidneys help the body by

a. removing extra body heat.

b. filtering wastes from blood.

c. removing carbon dioxide.

d. absorbing waste through the walls of villi.

26. How does the digestive system work?

a. carries oxygen and glucose to the cells.

b. allows blood that passes through the lungs to drop off $\mathrm{CO} 2$ and pick up $\mathrm{O} 2$

c. eliminates waste products from the body

d. breaks down food into nutrients (including glucose)

27. How does the respiratory system work?

a. carries oxygen and glucose to the cells.

b. breaks down food into nutrients (including glucose)

c. eliminates waste products from the body

d. allows blood that passes through the lungs to drop off $\mathrm{CO} 2$ and pick up $\mathrm{O} 2$

28. How does the circulatory system work?

a. carries oxygen and glucose to the cells.

b. allows blood that passes through the lungs to drop off $\mathrm{CO} 2$ and pick up $\mathrm{O} 2$

c. eliminates waste products from the body

d. breaks down food into nutrients (including glucose) 
29. How does the excretory system work?

a. carries oxygen and glucose to the cells.

b. allows blood that passes through the lungs to drop off $\mathrm{CO} 2$ and pick up $\mathrm{O} 2$

c. eliminates waste products from the body

d. breaks down food into nutrients (including glucose)

30. Combine efforts to break down food and transport it to cells

a. digestive and circulatory systems

b. digestive and excretory systems

c. respiratory and circulatory systems

d. respiratory and muscular systems

31. Combine efforts to support and protect the internal organs

a. digestive and circulatory systems

b. muscular and skeletal systems

c. respiratory and circulatory systems

d. integumentary and skeletal systems

32. Which organ is not in the respiratory system?
a. nose
b. pancreas
c. bronchi
d. trachea 
33. What tube is part of the digestive system that is between the mouth and the stomach?
a. trachea
b. esophagus
c. ureters
d. nephrons

34. What is the main job of the excretory system?

a. to break down foods into nutrients that can be used by the body.

b. take in oxygen and exhale waste like carbon dioxide.

c. to filter toxins and excess water out of cells.

d. take in oxygen and exhale waste like carbon dioxide.

35. How many chambers are there in the human heart?
a. one
b. four
c. three
d. two 
Appendix J: Student Engagement Checklist

\begin{tabular}{|c|c|c|c|c|c|c|}
\hline Observations & Very High & High & Medium & Low & Very Low & N/A \\
\hline $\begin{array}{l}\text { Positive Body Language - } \\
\text { Student exhibits body postures } \\
\text { that indicate he/she is paying } \\
\text { attention to the teacher and/or } \\
\text { other students }\end{array}$ & & & & & & \\
\hline $\begin{array}{l}\text { Consistent Focus/Time On } \\
\text { Task/Engagement - Student is } \\
\text { focused on the learning activity } \\
\text { with minimal disruptions. Student } \\
\text { is engaged with the current task }\end{array}$ & & & & & & \\
\hline $\begin{array}{l}\text { Verbal Participation - Student } \\
\text { expresses thoughtful ideas, } \\
\text { reflective answers, and questions } \\
\text { are relevant or appropriate to } \\
\text { learning }\end{array}$ & & & & & & \\
\hline $\begin{array}{l}\text { Individual Attention - Student } \\
\text { feels comfortable seeking help and } \\
\text { asking questions }\end{array}$ & & & & & & \\
\hline $\begin{array}{l}\text { Student Interaction with Peers- } \\
\text { Student interacts with and offers } \\
\text { assistance to other students } \\
\text { instead of asking questions }\end{array}$ & & & & & & \\
\hline $\begin{array}{l}\text { Fun and Excitement - Student } \\
\text { exhibits interest and enthusiasm } \\
\text { and uses positive humor }\end{array}$ & & & & & & \\
\hline $\begin{array}{l}\text { Meaningfulness of Work - } \\
\text { Student finds the work interesting, } \\
\text { challenging, and connected to } \\
\text { learning }\end{array}$ & & & & & & \\
\hline $\begin{array}{l}\text { Overall Level of Student } \\
\text { Engagement }\end{array}$ & & & & & & \\
\hline
\end{tabular}

Adapted from:

Jones, PhD, R. D. (2009). Student engagement teacher handbook. Rexford, New York: International Center for Leadership in Education. Retrieved from http://www.leadered.com/pdf/Student Engage handbook excerpt.pdf 
Appendix K: Class Engagement Checklist

\begin{tabular}{|c|c|c|c|c|c|c|}
\hline Observations & Very High & High & Medium & Low & Very Low & $\mathbf{N} / \mathbf{A}$ \\
\hline $\begin{array}{l}\text { Positive Body Language }- \text { Students } \\
\text { the classroom generally exhibit body } \\
\text { postures that indicate they are paying } \\
\text { attention to the teacher and/or other } \\
\text { students (actively listening, questionir } \\
\text { etc.) }\end{array}$ & & & & & & \\
\hline $\begin{array}{l}\text { Consistent Focus/Time On } \\
\text { Task/Engagement - The class is focu } \\
\text { on the learning activity with minimal } \\
\text { disruptions. Student is engaged with } t \\
\text { current task }\end{array}$ & & & & & & \\
\hline $\begin{array}{l}\text { Verbal Participation - Students are } \\
\text { expressing thoughtful ideas, voluntee } \\
\text { reflective answers, and their question } \\
\text { are relevant or appropriate to learnin }\end{array}$ & & & & & & \\
\hline $\begin{array}{l}\text { Individual Attention - Students in th } \\
\text { class feel comfortable seeking help an } \\
\text { asking questions }\end{array}$ & & & & & & \\
\hline $\begin{array}{l}\text { Student Interaction with Peers-Stud } \\
\text { interacts with and offers assistance to } \\
\text { other students instead of asking } \\
\text { questions }\end{array}$ & & & & & & \\
\hline $\begin{array}{l}\text { Fun and Excitement - Students in th } \\
\text { class are exhibiting interest and } \\
\text { enthusiasm and using positive humor }\end{array}$ & & & & & & \\
\hline $\begin{array}{l}\text { Meaningfulness of Work - The class } \\
\text { finds the work interesting, challenging } \\
\text { and connected to learning }\end{array}$ & & & & & & \\
\hline Overall Level of Class Engagement & & & & & & \\
\hline
\end{tabular}

Adapted from:

Jones, PhD, R. D. (2009). Student engagement teacher handbook. Rexford, New York: International Center for Leadership in Education.Retrieved from http://www.leadered.com/pdf/Student Engage handbook excerpt.pdf 
Appendix L: Data Sources

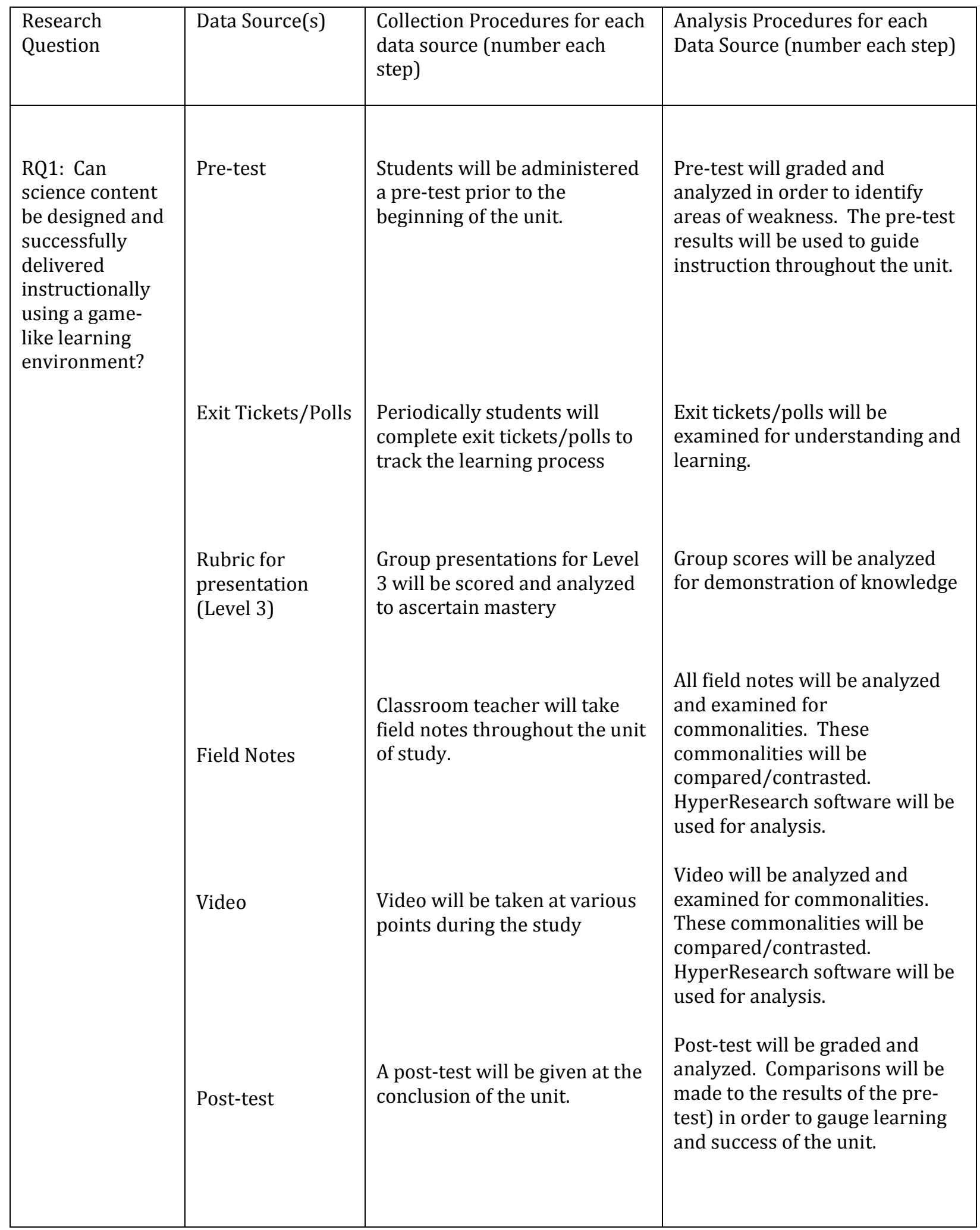




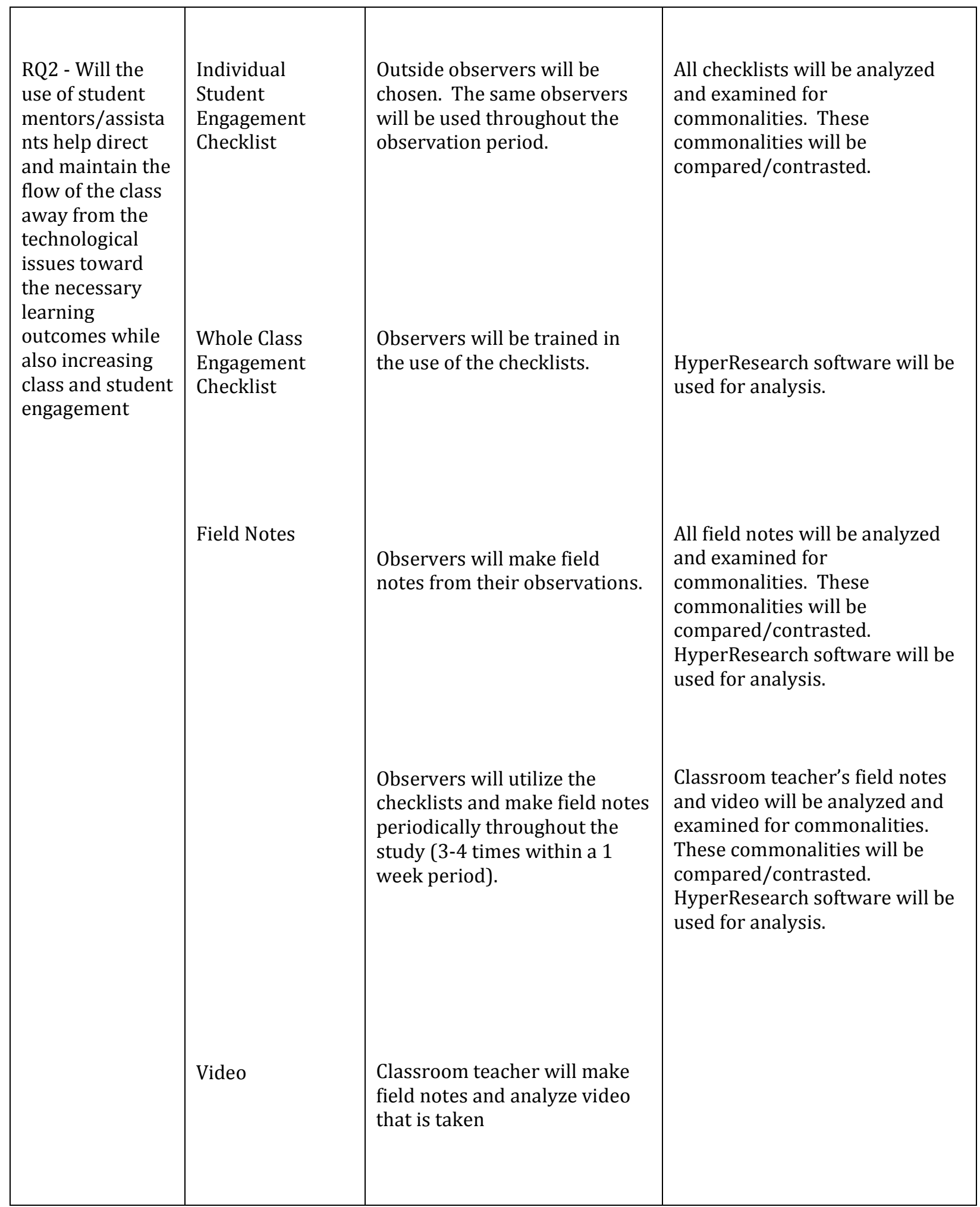

